\title{
Potential Impact of Flexible CHP on the Future Electric Grid in California
}

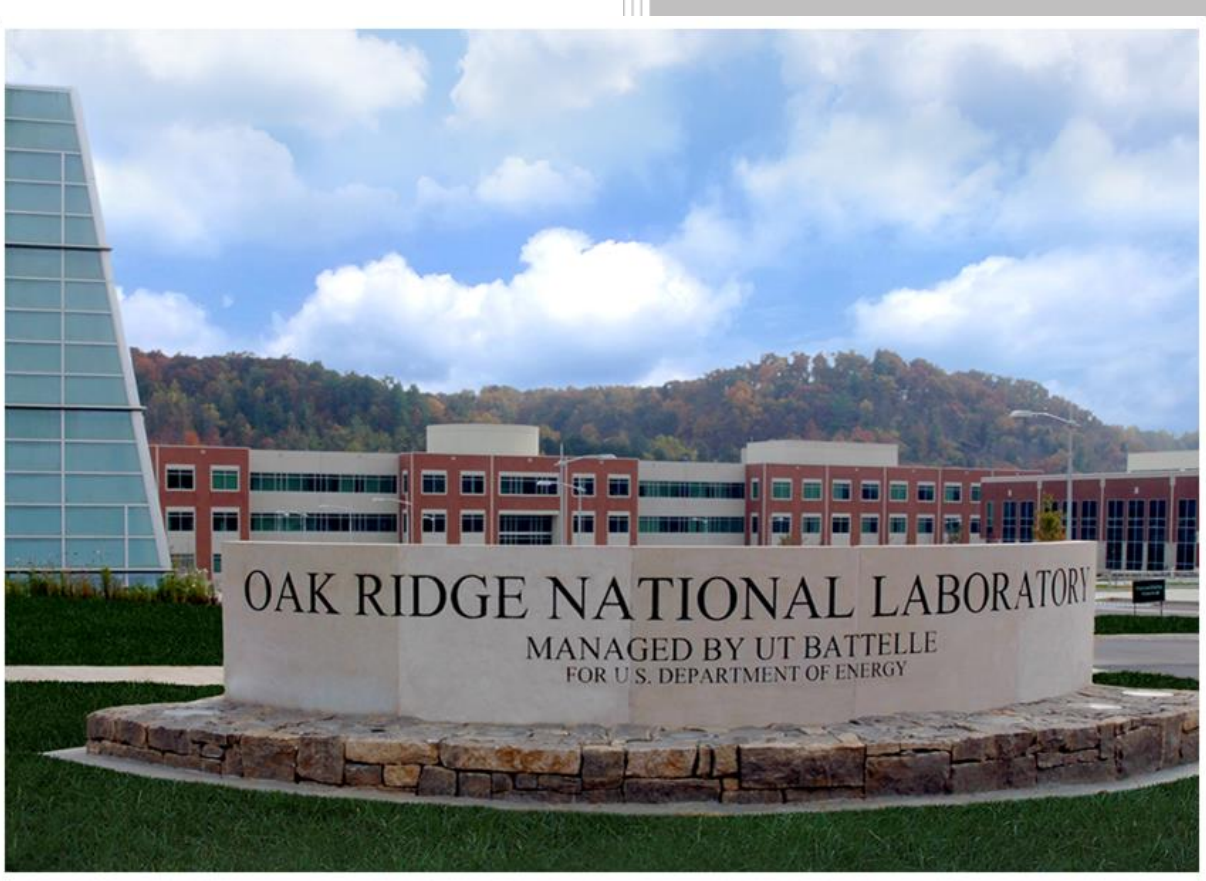

Jal Desai

Mark Ruth

Paul Lemar

Mahabir Bhandari

John Storey

Kiran Srivastava

Jonathan Rogers

Harrison Schwartz

August 2020 


\section{DOCUMENT AVAILABILITY}

Reports produced after January 1,1996, are generally available free via US Department of Energy (DOE) SciTech Connect.

Website www.osti.gov

Reports produced before January 1, 1996, may be purchased by members of the public from the following source:

National Technical Information Service

5285 Port Royal Road

Springfield, VA 22161

Telephone 703-605-6000 (1-800-553-6847)

TDD 703-487-4639

Fax 703-605-6900

E-mail info@ntis.gov

Website http://classic.ntis.gov/

Reports are available to DOE employees, DOE contractors, Energy Technology Data Exchange representatives, and International Nuclear Information System representatives from the following source:

Office of Scientific and Technical Information

PO Box 62

Oak Ridge, TN 37831

Telephone 865-576-8401

Fax 865-576-5728

E-mail reports@osti.gov

Website http://www.osti.gov/contact.html

This report was prepared as an account of work sponsored by an agency of the United States Government. Neither the United States Government nor any agency thereof, nor any of their employees, makes any warranty, express or implied, or assumes any legal liability or responsibility for the accuracy, completeness, or usefulness of any information, apparatus, product, or process disclosed, or represents that its use would not infringe privately owned rights. Reference herein to any specific commercial product, process, or service by trade name, trademark, manufacturer, or otherwise, does not necessarily constitute or imply its endorsement, recommendation, or favoring by the United States Government or any agency thereof. The views and opinions of authors expressed herein do not necessarily state or reflect those of the United States Government or any agency thereof. 
Energy and Transportation Science Division

MODELING THE IMPACT OF FLEXIBLE CHP ON THE FUTURE ELECTRIC GRID IN CALIFORNIA

\author{
Jal Desai ${ }^{1}$ \\ Mark Ruth ${ }^{1}$ \\ Paul Lemar ${ }^{2}$ \\ Mahabir Bhandari ${ }^{3}$ \\ John Storey ${ }^{3}$ \\ Kiran Srivastava ${ }^{4}$ \\ Jonathan Rogers 5 \\ Harrison Schwartz
}

${ }^{1}$ National Renewable Energy Laboratory

${ }^{2}$ Resource Dynamics Corporation

${ }^{3}$ Oak Ridge National Laboratory

${ }^{4}$ Booz Allen Hamilton

${ }^{5}$ Energetics, Inc.

August 2020

Prepared by

OAK RIDGE NATIONAL LABORATORY

Oak Ridge, TN 37831-6283

managed by

UT-BATTELLE, LLC

for the

US DEPARTMENT OF ENERGY

under contract DE-AC05-00OR22725 



\section{CONTENTS}

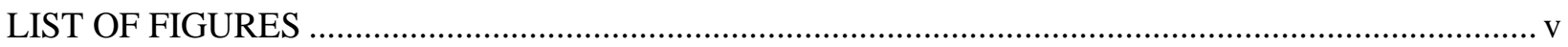

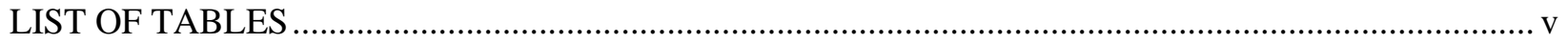

ABBREVIATIONS, ACRONYMS, AND INITIALISMS ….................................................... vii

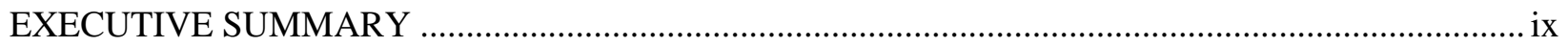

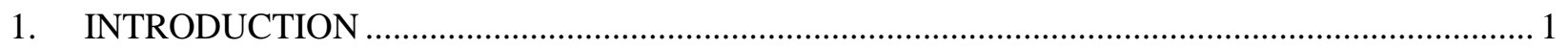

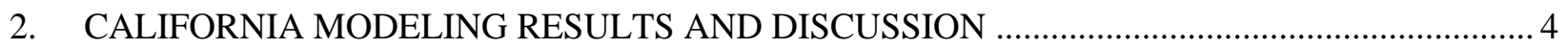

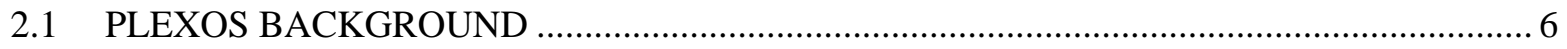

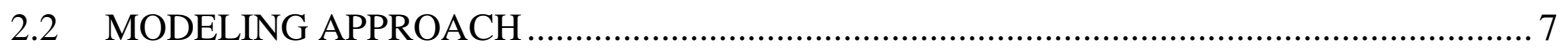

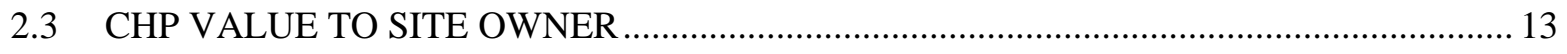

2.3.1 Potential Revenue Stream from Capacity Payments................................................. 15

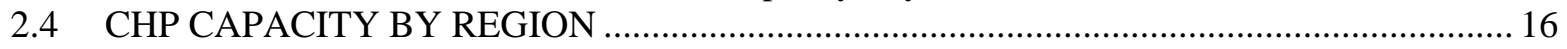

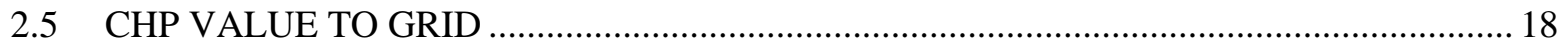

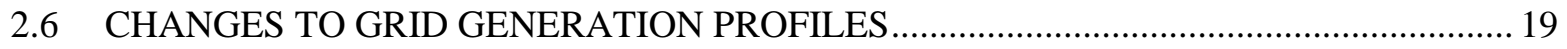

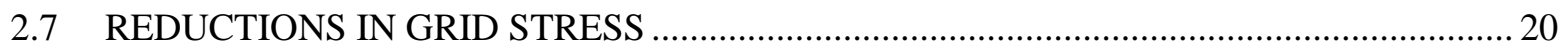

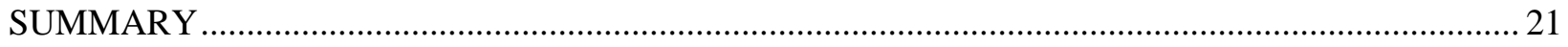

APPENDIX A. MODELING PARAMETERS AND SOURCES …............................................. A-1

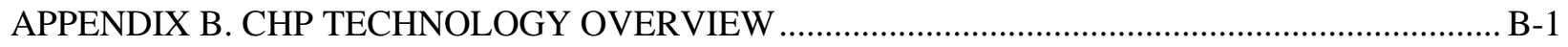

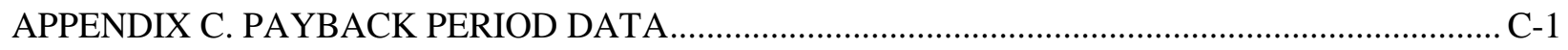

APPENDIX D. VARIABLE COST TO GENERATE AMONG TYPES OF GRID GENERATION ....D-1

APPENDIX E. APPROACH TO VALUING THERMAL LOAD …................................................. E-1 



\section{LIST OF FIGURES}

Figure ES1. Overview of annual grid and site owner value for Traditional, Advanced, and Combined scenarios (or \$3.4K/year, \$153K/year, and \$165K/year per MW of additional CHP capacity respectively).

Figure ES2. Overview of grid and site owner value for traditional, advanced, and combined scenarios

Figure 1. Operating profiles of Traditional and Advanced CHP units.

Figure 2. Flow chart depicting PLEXOS modeling runs for the Traditional, Advanced, and Combined scenarios.

Figure 3. California independent system operator day-ahead price, August 6, 2019.

Figure 4. Average site payback periods for CHP units over and under $5 \mathrm{MW}$ for Traditional, Advanced, and Combined scenarios (payback periods do not include capacity payments).

Figure 5. The effects of payback periods for Advanced CHP units. grid revenues (GR), and capacity payments $(\mathrm{CP})$ on the payback period are compared (further details are available in Appendix B).....

Figure 6. Heat maps showing installed CHP capacity in modeled California utility regions for Reference, Traditional, Advanced, and Combined scenarios. .................................................. 17

Figure 7. Annual California grid operating cost savings compared with Reference scenario.

Figure 8. Annual grid generation profile for the Traditional, Advanced, and Combined CHP scenarios relative to the Reference scenario.

Figure 9. Annual high-stress grid hours by region.

\section{LIST OF TABLES}

Table 1. How flexible CHP can support grid modernization................................................................ 1

Table 2. Examples of grid services that are and are not compensated in most electricity markets. ............. 2

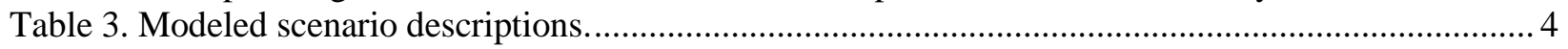

Table 4. Comparison of CHP grid support configurations. ................................................................... 5

Table 5. Descriptions of California modeling scenarios........................................................................ 7

Table 6. Dispatch stack of weighted average cost to generate................................................................ 12

Table 7. Summary of annual energy and ancillary service revenues (surplus only) by scenario and

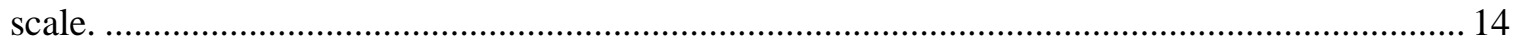

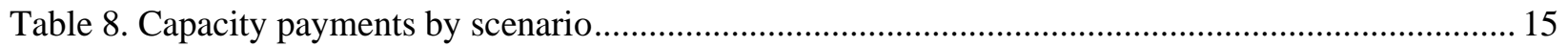

Table 9. Maximum CHP capacity and number of sites by region for each California modeled scenario. 



\section{ABBREVIATIONS, ACRONYMS, AND INITIALISMS}

$\begin{array}{ll}\text { BLS } & \text { Bureau of Labor Statistics } \\ \text { BTU } & \text { British thermal unit } \\ \text { CAISO } & \text { California Independent System Operator } \\ \text { CC } & \text { Combined cycle } \\ \text { CEC } & \text { California Energy Commission } \\ \text { CHP } & \text { Combined heat and power } \\ \text { CONE } & \text { Cost of new entry } \\ \text { CP } & \text { Capacity payments } \\ \text { CT } & \text { Combustion turbine } \\ \text { DER } & \text { Distributed energy resources } \\ \text { DISPERSE } & \text { DIStributed Power Economic Rationale Selection Model } \\ \text { DOE } & \text { Department of Energy } \\ \text { EIA } & \text { Energy Information Administration } \\ \text { GHG } & \text { Greenhouse gas } \\ \text { GR } & \text { Grid revenues } \\ \text { GW } & \text { Gigawatt } \\ \text { HHV } & \text { Higher heating value } \\ \text { HR } & \text { Heat rate } \\ \text { ISO } & \text { Independent system operator } \\ \text { ISO-NE } & \text { Independent System Operator - North East } \\ \text { kW } & \text { kilowatt } \\ \text { kWh } & \text { kilowatt per hour } \\ \text { LADWP } & \text { Los Angeles Department of Water and Power } \\ \text { LCGS } & \text { Low Carbon Grid Study } \\ \text { MMBTU } & \text { Million British thermal units } \\ \text { MW } & \text { Megawatt } \\ \text { MWh } & \text { Megawatt per hour } \\ \text { NREL } & \text { National Renewable Energy Laboratory } \\ \text { NYISO } & \text { New York Independent System Operator } \\ \text { O\&M } & \text { Operation and maintenance } \\ \text { ORNL } & \text { Oak Ridge National Laboratory } \\ \text { PGE } & \text { Pacific Gas and Electric } \\ \text { PJM } & \text { Pennsylvania New Jersey Maryland Interconnection } \\ \text { PV } & \text { Photovoltaic (solar cell) } \\ \text { RDC } & \text { Resource Dynamics Corporation } \\ \text { RPS } & \text { Renewable Portfolio Standard } \\ \text { STIG } & \text { Steam injection gas turbine } \\ \text { UC } & \text { University of California } \\ \text { VO\&M } & \text { Variable operation and maintenance } \\ \text { WECC } & \text { Western Electricity Coordinating Council } \\ & \end{array}$





\section{EXECUTIVE SUMMARY}

The US electric grid is changing fundamentally: not only are the generation sources that supply the grid changing, but so too are the profiles of the loads that use the electricity. Traditionally, generation followed a fairly predictable demand pattern, which allowed a baseload fossil fuel generation infrastructure to run constantly at a high capacity factor to meet the minimum load, with less capitalintensive, flexible generation used to meet the additional varying load. However, recently, the country began shifting fossil generation moved from coal-based to natural gas-powered electricity generation, and renewable generation has increased steadily. In California, utility-scale renewable energy generation has grown more rapidly than in many other states. In $2018,{ }^{1} 34 \%$ of California's retail electricity sales were provided by renewable energy resources, and these sales are expected to continue to grow. California recently passed a bill mandating a Renewable Portfolio Standard goal of $100 \%$ zero-carbon electricity generation on its grid by 2045 .

Renewable energy generation from wind and solar photovoltaic (PV) sources is variable and dependent upon the resource (the amount of sunshine or wind at the time of generation). Variable generation brings new challenges to a grid originally designed for baseload power. Additional technologies are required to meet the challenges and operate the grid effectively. The impacts are both in the bulk power system and more localized. As consumers adopt rooftop solar PV panels, the net electricity demand drops during daytime hours and increases steeply to a peak in the evenings when PV systems stop generating electricity. This "duck curve" puts stress on the grid and requires California's grid operator to curtail generation from renewable resources during the day and then later ramp up output from conventional generation to meet the rapidly escalating evening electricity demand in the state. ${ }^{2}$ Natural gas generation is the current solution because of its flexibility and cost profile-which is impacted more by demand for gas than by capital expense. However, more efficient solutions would better support the state's greenhouse gas (GHG) emissions reduction goals.

How can energy technologies mitigate intermittent renewable generation coming onto the grid? How can the grid become responsive to the changes in demand and load profiles created by developments ranging from higher energy efficiency to distributed generation to smart appliances to increased end-use electrification to increased interoperability of loads? The solution is unlikely to come from one single technology or policy change, but rather from embracing a variety of technologies across all sectors and approaches to helping all sectors transition to thinking about and using energy differently. Technologies of the future require flexibility and advanced control mechanisms to respond to changing requirements. One example is combined heat and power (CHP) technology.

CHP is a technology that was historically used most extensively by the industrial sector, with its largescale electricity and heat demands. CHP allows for the use of heat generated concurrently with power generation to be used for industrial and building needs - space and water heating and cooling, as well as other thermal loads. The utilization of what would normally be wasted heat results in a highly efficient power generation technology — up to $85 \%$ overall efficiency.

The high efficiency of CHP also results in financial savings for the owner by reducing the need to purchase grid electricity, and it reduces the need to generate steam or hot water using a separate boiler, reducing the consumption of natural gas use as a boiler fuel. CHP has been used for decades, usually to

\footnotetext{
1 "California Energy Commission-Tracking Progress." California Energy Commission, May 2019, accessed at https://www.energy.ca.gov/sites/default/files/2019-05/renewable.pdf.

2 "Managing Oversupply." California ISO webpage and data, accessed at caiso.com/informed/Pages/ManagingOversupply.aspx.
} 
meet the electrical load while reducing the thermal load. "Flexible CHP"3 technologies are being developed that efficiently provide both a baseload that meets the site's electrical load and a surplus that can be sold to the grid when the electricity price is high. Coupled with changes in grid operations, flexible CHP technologies may have more opportunities for adoption within the industrial sector than traditional technologies. In most locations, the additional thermal generation by the CHP units would reduce some of the remaining use of boilers to generate heat. This flexible CHP approach would provide a distributed energy resource that the grid could call upon during times of high net demand. CHP owners would generate revenue from selling the excess electricity to partly offset the capital cost of owning and operating large CHP systems. The benefits of increased adoption of CHP are numerous ${ }^{4}$ :

- GHG emissions are lower, compared with traditional fossil-fuel based power generation, because of the higher efficiency of CHP.

- Where energy prices and usage patterns are conducive, CHP lowers costs for businesses, helping them become more competitive.

- CHP provides a distributed grid resource that contributes to reliability and energy security.

However, for these benefits to be realized, there must be sufficient financial value to the grid as a whole.

This report describes an analysis of the potential financial value of both traditional and advanced, flexible CHP units in California. A multi-organizational team that included representatives from the National Renewable Energy Laboratory (NREL), Resource Dynamics Corporation (RDC), Oak Ridge National Laboratory (ORNL), Booz Allen Hamilton, and Energetics, Inc. performed this analysis. The team used cost-benefit analysis techniques to identify sites where CHP units could be installed and are likely to meet a payback period requirement (i.e., meet profitability requirements). Using those sites and a production cost model of the California electricity grid, the team estimated the impacts on the cost of operating the grid with those CHP units and compared them to the cost of operating the grid without the CHP resources.

The intent of this report is to inform decision-makers who are determining budgets for CHP technology research and development (R\&D). The results should enable those decision-makers to compare potential benefits of CHP technology improvements to potential impacts of other R\&D opportunities. The impact estimates can also inform decisions regarding where to focus CHP R\&D by comparing the magnitude of the various value streams.

To estimate the financial impacts to the grid, the analysis team modeled several scenarios, which are detailed in the following table. The scenarios aim to show the potential for flexible CHP in California and its possible impacts on grid operating costs. The Traditional, Advanced, and Combined scenarios have about 1,400 more CHP sites in California than the Reference scenario because those sites were assumed not to have CHP in the Reference Scenario's source. ${ }^{5}$

\footnotetext{
${ }^{3}$ Department of Energy Advanced Manufacturing Office Technical Fact Sheet. Flexible Combined Heat and Power (CHP) Systems - Fact Sheet, 2018, accessed at https://www.energy.gov/eere/amo/downloads/flexible-combined-heat-and-power-chp-systems-fact-sheet-2018.

${ }^{4}$ A. Shipley, A. Hampton, B. Hedman, et al. Combined Heat and Power: Effective Energy Solutions for a Sustainable Future, Oak Ridge National Laboratory, December 2008, accessed at https://info.ornl.gov/sites/publications/files/Pub13655.pdf.

${ }^{5}$ G. Brinkman, J. Jorgenson, A. Ehlen, and J. H. Caldwell. Low Carbon Grid Study: Analysis of a 50\% Emission Reduction in California, NREL/TP-6A20-64884, January 2016, accessed at nrel.gov/docs/fy16osti/64884.pdf.
} 


\begin{tabular}{|l|l|c|}
\hline \multicolumn{1}{|c|}{ Modeled scenarios } & \multicolumn{1}{|c|}{ Description } & CHP capacity \\
\hline Reference & $\begin{array}{l}\text { Assumes a grid with 33\% renewables based on the } \\
\text { National Renewable Energy Laboratory's Low Carbon } \\
\text { Grid Study. In this scenario, existing CHP units in } \\
\text { California continue to serve site loads but are not earning } \\
\text { grid revenue }\end{array}$ & $\mathbf{3 4 0 0 ~ M W}$ \\
\hline Traditional & $\begin{array}{l}\text { In addition to the existing 3,400 MW of reference CHP } \\
\text { capacity in California, adds more CHP systems where } \\
\text { economically viable, }{ }^{6} \text { with no assumption of technology } \\
\text { advancement. However, the capacity is used in a more } \\
\text { flexible manner to support the grid }\end{array}$ & $\mathbf{7 5 0 0}$ MW \\
\hline Advanced & $\begin{array}{l}\text { Adds additional CHP over the reference scenario, } \\
\text { assuming that CHP has advanced from a technology } \\
\text { perspective and can flexibly respond to grid demand } \\
\text { requirements }\end{array}$ & $\mathbf{8 1 0 0}$ MW \\
\hline Combined & $\begin{array}{l}\text { Considers a blended scenario of advanced CHP adoption } \\
\text { in which sites with CHP units sized 5 MW or greater } \\
\text { deploy advanced technology, and the remaining suitable } \\
\text { sites deploy traditional CHP, based on which technology } \\
\text { is economically viable }\end{array}$ & \\
\hline
\end{tabular}

The analysis team estimated a significant effect on the operating cost of the California grid owing to the displacement of imports, as well as traditional combined-cycle baseload and peaking plants currently on the system. In addition, the Traditional, Advanced, and Combined scenarios lower the number of grid stress hours, when energy prices exceed the most expensive marginal cost technologies available to the independent system operator.

As shown in Figure ES1, all modeled scenarios estimate that site owners receive sufficient revenue to support an investment in CHP-\$14 million/year, \$770 million/year, and \$780 million/year in revenue for site owners (or $\$ 3.4 \mathrm{~K} /$ year, $\$ 153 \mathrm{~K} /$ year, and $\$ 165 \mathrm{~K} /$ year per MW of additional CHP capacity, respectively) - by selling power to the grid for the Traditional, Advanced, and Combined scenarios, respectively. In addition, using a $\$ 20 / \mathrm{kW} /$ year capacity payment (which represents current California conditions), owners could receive an additional \$149 million, \$168 million, and \$162 million under the Traditional, Advanced, and Combined, scenarios, respectively, if the CHP system could receive this payment for providing capacity to the grid in California. The payback period to site owners was calculated by dividing the installed cost of a system by the total savings to the owner.

\footnotetext{
${ }^{6}$ The term "economically viable" refers to the ability of the unit to repay the owner with grid revenues within 6
} years or less. 


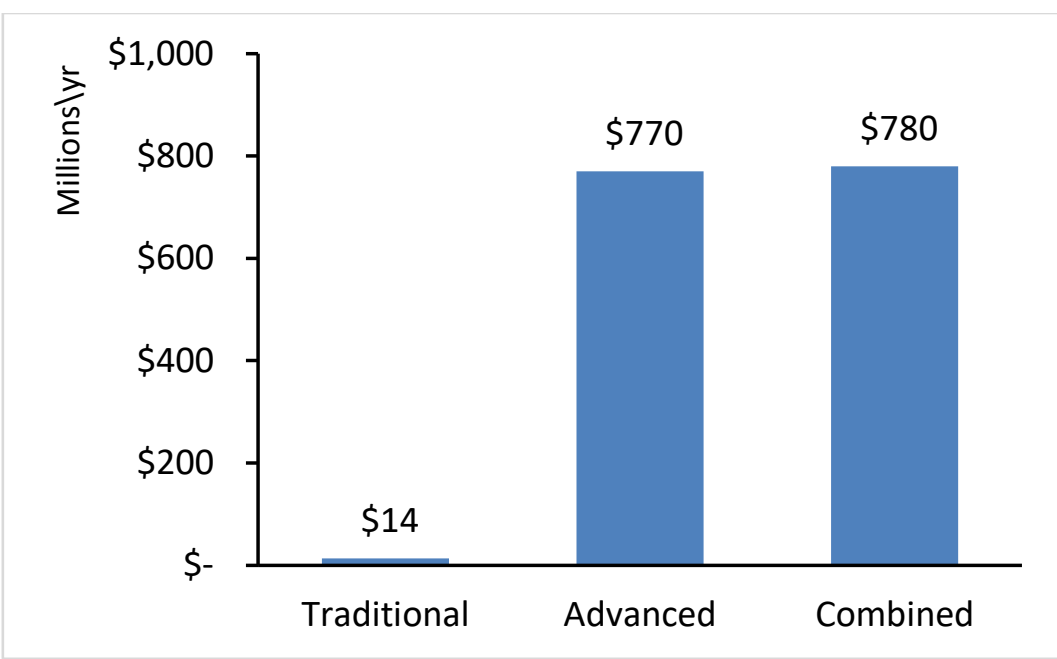

Figure ES1. Overview of annual grid and site owner value for Traditional, Advanced, and Combined scenarios (or \$3.4K/year, \$153K/year, and \$165K/year per MW of additional CHP capacity respectively).

For modeling purposes, the analysis team retained all sites that had payback periods of 6 years or less, with the recognition that some owners are likely to require shorter payback periods to invest in flexible CHP. The total savings to the owner was calculated as reductions in grid purchases and boiler fuel, plus grid support revenue minus the CHP fuel and operations and maintenance cost.

This analysis also shows that the availability of CHP can provide significant value to the grid through the provision of energy as well as contingency and regulation ancillary services. The Traditional, Advanced, and Combined scenarios show \$497 million (3.7\%), \$904 million (6.8\%), and \$728 million (5.5\%) in grid value, respectively, as illustrated in Figure ES2.

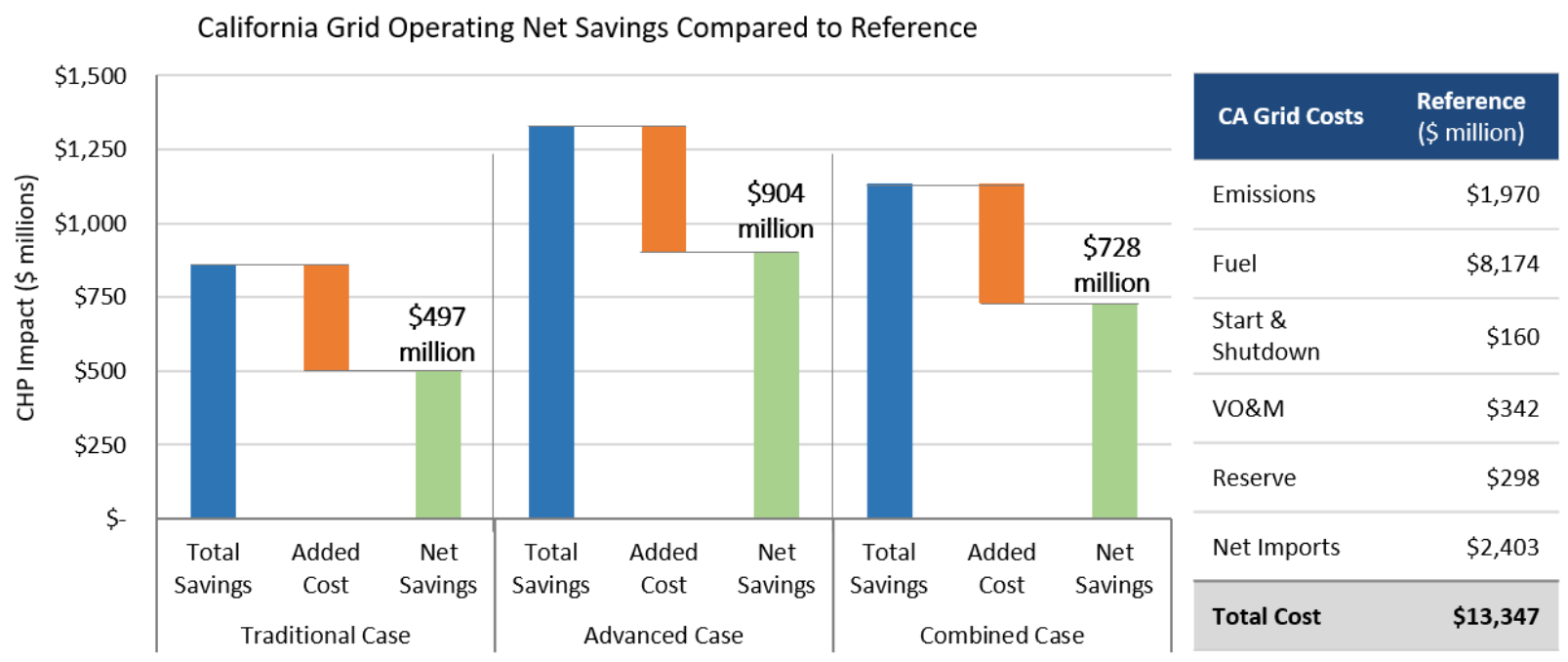

Figure ES2. Overview of grid and site owner value for traditional, advanced, and combined scenarios.

CHP can help grid operations in ways that are difficult to monetize. One example is a reduction in grid stress hours - hours when energy prices exceed the cost of the most expensive generator, thus indicating a need for imports and other possible limitations The Traditional, Advanced, and Combined scenarios showed a complete elimination of grid stress hours, showcasing how CHP can provide grid services when they are needed most and eliminate reliance on expensive resources. 


\section{INTRODUCTION}

Combined heat and power (CHP) systems provide electricity and process heat at more than 4,400 industrial and commercial facilities across the United States. ${ }^{7}$ Typically fueled with natural gas, a CHP system combines a prime mover (such as a reciprocating engine) with a generator and heat recovery equipment, allowing operation at very high efficiencies $(65-85 \%){ }^{8}$ Traditionally, CHP systems have been configured to serve local electrical and thermal loads at the sites where they are deployed. Units are sized to ensure a high capacity factor for the equipment, and the electricity generated tends to be used on site. CHP units in the United States already generate over $12 \%$ of the nation's electricity. ${ }^{9}$

However, CHP's potential benefits could be much greater if power generated could be used beyond the site, because the analysis was performed under the assumption that sites could use all the thermal output. Analysis of a few key sectors confirmed that this assumption is valid (for more information, see Appendix E). Those benefits could include improved grid reliability and resilience, as well as lower-cost options for providing energy and other grid services. The potential benefits also align well with grid modernization objectives, as shown in Combined heat and power (CHP) systems provide electricity and process heat at more than 4,400 industrial and commercial facilities across the United States., and greater electrification of loads, driven by carbon reduction priorities.

Table 1. How flexible CHP can support grid modernization.

\begin{tabular}{|l|l|}
\hline \multicolumn{1}{|c|}{ Goal } & \multicolumn{1}{|c|}{ How flexible CHP supports the goal } \\
\hline Grid reliability & $\begin{array}{l}\text { Installations can improve power quality, provide ancillary services, and relieve } \\
\text { grid congestion }\end{array}$ \\
\hline Customer resilience & $\begin{array}{l}\text { Systems can allow critical loads to continue operation during grid outages and } \\
\text { provide dispatchable power for microgrids }\end{array}$ \\
\hline Energy efficiency & $\begin{array}{l}\text { CHP systems use less fuel and are more efficient, saving energy compared with } \\
\text { conventional, separate electricity generation and heat production }\end{array}$ \\
\hline DER integration & $\begin{array}{l}\text { CHP can help utilities integrate new renewable distributed energy resource } \\
\text { (DER) deployments and balance variable loads }\end{array}$ \\
\hline Locational value & $\begin{array}{l}\text { CHP can be deployed at strategic locations on the system where it is needed } \\
\text { most, thus relieving grid congestion }\end{array}$ \\
\hline Affordability & $\begin{array}{l}\text { CHP can often meet system needs more cost effectively than can investments in } \\
\text { traditional assets, thus lowering costs for ratepayers across the utility system }\end{array}$ \\
\hline Emissions Reductions & $\begin{array}{l}\text { Efficient CHP systems have lower emissions than conventional grid resources } \\
\text { and can be used to meet emissions reduction targets (e.g., states w/GHG goals) }\end{array}$ \\
\hline
\end{tabular}

Source: This table is taken from D. Jones and M. Kelly. Supporting Grid Modernization with Flexible CHP Systems, ICF International, 2017. https://www.icf.com/insights/energy/supporting-grid-modernization-with-flexible-chp-systems.

7 “U.S. DOE Combined Heat and Power Installation Database" (as of December 31, 2016). US Department of Energy, accessed at https://doe.icfwebservices.com/chpdb/.

${ }^{8}$ While various methods can be used to calculate total CHP system efficiency, CHP generally yields a higher combined amount of electricity and useful heat per unit of fuel consumed than can be attained in a separate heat and power (SHP) system. For more information on calculating CHP system efficiency, see the US Environmental Protection Agency Catalog of CHP Technologies. March 2015.

${ }^{9}$ US Department of Energy. Combined Heat and Power: A Clean Energy Solution, August 2012, accessed at https://www.epa.gov/sites/production/files/201507/documents/combined_heat_and_power_a_clean_energy_solution.pdf. 
When configured within a microgrid, CHP installations can provide resilience for host facilities, allowing them to continue operation during grid outages. This advantage improves power reliability for the host facility and can increase reliability for the surrounding utility grid by reducing congestion. Additionally, $\mathrm{CHP}$ can provide essential grid services through frequency response, voltage control, and ramping capabilities. ${ }^{10,11}$

Many of these grid benefits are not currently monetized in US electricity markets, which compensate market participants for a limited array of services including energy generation and capacity, frequency regulation, spinning and non-spinning reserves, supplemental reserves, voltage support, and black start service. Independent system operators (ISOs) and regional transmission organizations (RTOs) benefit from systems that provide all these (monetized and unmonetized) grid modernization services, such as CHP systems. An increase in accounting for these unmonetized services, both financially and otherwise, is likely to make CHP systems more attractive for installation. Error! Not a valid bookmark selfreference. lists examples of grid services that are and are not compensated in most electricity markets.

An increasing number of CHP owners, electric system operators, and electric utilities who seek to maximize the value of their investments are exploring how CHP can supply additional services to the electric grid. Some owners of large CHP units already participate in ancillary services markets, and even small CHP units are occasionally called upon by ISOs in certain markets to provide firm capacity during extreme grid events. By selling energy, ancillary services, or capacity more regularly in the future, CHP systems of all sizes could generate additional revenue and increase system cost effectivenessparticularly in the manufacturing sector, where system owners may find it difficult to generate the necessary return on investment in CHP systems.

Table 2. Examples of grid services that are and are not compensated in most electricity markets.

\begin{tabular}{|c|c|c|}
\hline $\begin{array}{l}\text { Compensated by most } \\
\text { electricity markets }\end{array}$ & \multicolumn{2}{|c|}{ Not compensated by most electricity markets } \\
\hline $\begin{array}{l}\text { Ancillary services } \\
\text { - Frequency control } \\
\text { - Spinning reserves } \\
\text { - Non-spinning reserves } \\
\text { - Supplemental reserves } \\
\text { - Voltage support } \\
\text { - Black start service } \\
\text { Bulk power capacity and } \\
\text { energy services } \\
\text { - Energy } \\
\text { - Generating capacity }\end{array}$ & $\begin{array}{l}\text { Indirect system benefits } \\
\text { - Reduced overall system electricity } \\
\text { production cost } \\
\text { - Reduced curtailments of variable } \\
\text { generation } \\
\text { - Reduced cycling and ramping of } \\
\text { conventional generating units } \\
\text { - Reduced system emissions } \\
\text { (depending on plant mix) }\end{array}$ & $\begin{array}{l}\text { Power system stability services } \\
\text { - Inertial response } \\
\text { - Governor response } \\
\text { Transmission benefits } \\
\text { - Transmission congestion relief } \\
\text { - Transmission investments deferral } \\
\text { Non-energy benefits } \\
\text { - Portfolio diversification } \\
\text { - Local economic development and } \\
\text { job creation } \\
\text { - Security of fuel supply }\end{array}$ \\
\hline
\end{tabular}

The literature shows that utility ownership of CHP systems located at customer sites with continuous thermal loads is a promising approach to gain new value from CHP for utilities doing business in a more traditional regulatory structure. CHP is often the least-cost resource because of its high efficiencies and

\footnotetext{
${ }^{10}$ D. Jones and M. Kelly. Supporting Grid Modernization with Flexible CHP Systems, ICF International, 2017, accessed at https://www.icf.com/insights/energy/supporting-grid-modernization-with-flexible-chp-systems.

${ }^{11}$ In this report, the general term "grid services" refers to any product CHP provides other than energy for site loads. Grid services can include energy, capacity, or ancillary services that are delivered to the electric grid.
} 
credit from steam sales. CHP can be deployed at strategic grid locations in a shorter timeframe than other utility generation options. ${ }^{12}$

Greater use of CHP to serve offsite loads and support the electric grid could provide system-wide benefits, including lower wholesale energy costs, decreased transmission congestion, and improved grid stability. Achieving this vision will require an evolution of today's market rules, interconnection processes, and CHP technology. This study assumes that this evolution has taken place and explores how additional CHP deployment might benefit the CHP system owners and the electric grid.

${ }^{12}$ A. Hampson and B. Hedman. Utility CHP: A Least-Cost Baseload Resource, ICF International, June 1, 2017, accessed at icf.com/resources/white-papers/2017/utility-chp-ownership. 


\section{CALIFORNIA MODELING RESULTS AND DISCUSSION}

The goal of the modeling effort is to examine the potential impact of flexible CHP systems on the electric grid in California under the assumption that the market evolution mentioned in Section 1 has taken place. Additionally, the modeling effort tests two core hypotheses:

1. Distributed generation and traditional CHP units can potentially provide grid support services but will need additional cost/performance attributes to make an impact.

2. Flexible CHP units can provide responsive, cost-competitive, generation while also meeting site loads, by sizing systems with surplus capacity.

For the benefits of CHP to be realized, there must be sufficient financial value to the grid as a whole. To estimate the financial impacts to the grid, the analysis team modeled a Reference scenario and three other scenarios: Traditional, Advanced, and Combined, as detailed in the following chart. The scenarios aim to show the potential for flexible CHP in California and its possible impacts on grid operating costs.

Table 3. Modeled scenario descriptions.

\begin{tabular}{|l|l|c|}
\hline \multicolumn{1}{|c|}{ Modeled scenario } & \multicolumn{1}{|c|}{ Description } & CHP capacity \\
\hline Reference & $\begin{array}{l}\text { Assumes a grid with 33\% renewables based on the National } \\
\text { Renewable Energy Laboratory's Low Carbon Grid Study. In this } \\
\text { scenario, existing CHP units in California continue to serve site } \\
\text { loads but are not earning grid revenue }\end{array}$ & $\mathbf{3 4 0 0}$ MW \\
\hline Traditional & $\begin{array}{l}\text { In addition to the existing 3,400 MW of reference CHP capacity } \\
\text { in California, adds more CHP systems where economically } \\
\text { viable, }{ }^{13} \text { with no assumption of technology advancement. } \\
\text { However, the capacity is used in a more flexible manner to } \\
\text { support the grid }\end{array}$ & $\mathbf{7 5 0 0}$ MW \\
\hline Advanced & $\begin{array}{l}\text { Adds additional CHP over the reference scenario, assuming that } \\
\text { CHP has advanced from a technology perspective and can } \\
\text { flexibly respond to grid demand requirements }\end{array}$ & $\mathbf{8 4 0 0}$ MW \\
\hline Combined & $\begin{array}{l}\text { Considers a blended scenario of advanced CHP adoption in } \\
\text { which sites with CHP units sized 5 MW or greater deploy } \\
\text { advanced technology, and the remaining suitable sites deploy } \\
\text { traditional CHP, based on which technology is economically } \\
\text { viable }\end{array}$ & $\mathbf{8 1 0 0}$ MW \\
\hline
\end{tabular}

Table 3 provides a high-level comparison of the Traditional and Advanced CHP grid support configurations. ${ }^{13}$ The term "economically viable" refers to the ability of the unit to repay the owner with grid revenues within 6
years or less. 
Table 4. Comparison of CHP grid support configurations.

\begin{tabular}{|c|c|c|}
\hline Configuration & Grid support & Other benefits \\
\hline \multicolumn{3}{|c|}{ Traditional: Primarily serve on-site electrical loads and are not ramped to support the grid } \\
\hline $\begin{array}{l}\text { CHP sized to baseload } \\
\text { but allowed to operate } \\
\text { at } 10 \% \text { overcapacity } \\
\text { to provide grid } \\
\text { services }\end{array}$ & $\begin{array}{l}\text { Limited to } 10 \% \text { of capacity for } 500 \text { hours per } \\
\text { year }^{14}\end{array}$ & $\begin{array}{l}\text { Limited, could support critical loads } \\
\text { during grid outage }\end{array}$ \\
\hline \multicolumn{3}{|c|}{ Advanced: Serve site loads and use surplus capacity to provide a range of services to the grid } \\
\hline $\begin{array}{l}\text { CHP sized between } \\
\text { baseload and peak } \\
\text { load }\end{array}$ & $\begin{array}{l}\text { More active, limited to } 25 \% \text { and } 500 \text { hours per } \\
\text { year }{ }^{15}\end{array}$ & $\begin{array}{l}\text { Could support all loads during grid } \\
\text { outage }\end{array}$ \\
\hline $\begin{array}{l}\text { CHP sized above peak } \\
\text { load }\end{array}$ & $\begin{array}{l}\text { Provides up to } 40 \% \text { of the its capacity reserved } \\
\text { for grid support, without constraints }\end{array}$ & $\begin{array}{l}\text { Could support all loads during grid } \\
\text { outage }\end{array}$ \\
\hline
\end{tabular}

The key difference between the Traditional and Advanced CHP units is the available surplus capacity of the CHP units that can be dispatched to provide grid services. ${ }^{16}$ Traditional CHP systems are designed and built to serve site loads; however, they can also use up to $10 \%$ of their capacity to provide energy and other services to the grid for short periods of time. Advanced CHP systems are sized to serve site loads but can provide up to $40 \%$ more power than the baseload capacity and do so for longer periods of time. The overcapacity limits depend on the site and the CHP unit. The differences between the baseload and surplus capacity configurations of these units can be seen in Error! Reference source not found.. A dvanced CHP technologies included the following:

1. Reciprocating engines with inverters. Reciprocating engine CHP units coupled with inverter technology offer operation at higher output than reciprocating engines without inverters $(125 \%$ and $110 \%$, respectively, in this analysis). Thus, they create surplus capacity that can be used to support the grid, but the period for which they can run at higher capacities is limited. The analysis assumed that reciprocating engine units of up to $5 \mathrm{MW}$ included inverter technology and could operate at over $100 \%$ and up to $125 \%$ of rated power for as many as 500 hours per year.

2. Oversized reciprocating engines. Reciprocating engine CHP units tend to be very efficient at part load, down to $50 \%$ of full load or less. CHP units can be sized for greater capacity than the site baseload to include surplus capacity that can be used to support the grid. The analysis sized partloaded reciprocating engine CHP units at 60 or $75 \%$ of full capacity for greater than $5 \mathrm{MW}$ site use and made the balance available for grid support, using technology available today. This option was not constrained in terms of hours of operation.

\footnotetext{
${ }^{14}$ CHP unit specifications allow for these levels of grid support.

15 Assumption chosen to avoid additional maintenance costs or needs for the CHP units.

${ }^{16}$ A detailed description of CHP technologies is included in Appendix B.
} 


\section{Operation at $1 \mathrm{MW}$ for Traditional and Advanced CHP Units}

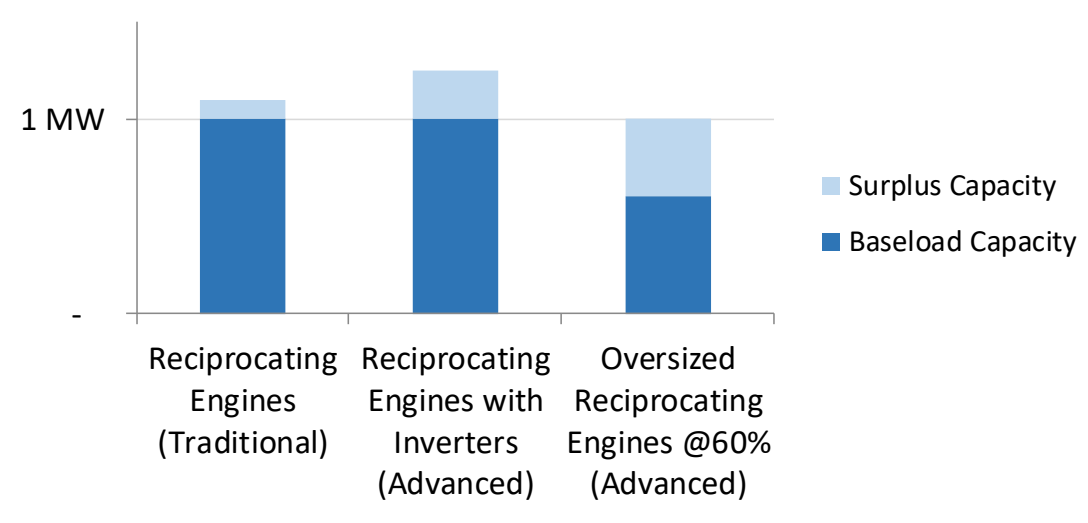

Figure 1. Operating profiles of Traditional and Advanced CHP units.

These configurations were deployed in several different scenarios for a given region in California to independently evaluate and determine value created for a CHP site operator and the value created for the grid. The regions in this approach were the balancing areas in California described in Section 2.4.

In developing the concepts of advanced CHP, both gas turbine and reciprocating engine concepts were characterized. Concepts deploying steam injection with gas turbines, which were pioneered in the late 1970s and early 1980s, were evaluated for their attractive generating efficiencies. That technology eventually was displaced by combined-cycle turbines, which are still the most prevalent form of natural gas-fired generation but are not typically employed at the scale for which CHP units are sized. A CHP unit employing steam injection is still a practical option to temporarily increase generation efficiency. However, the impact of supplying thermal energy to replace the thermal energy used for steam injection resulted in a lower efficiency when both thermal and electric outputs were considered, as is critical for CHP concepts. Ultimately in the analysis, the reciprocating engine options were found to be economically preferable and thus are the only options included in the final results. Appendix $\mathrm{C}$ summarizes the options considered and the relative performance of each.

To develop the scenarios, experts from Oak Ridge National Laboratory (ORNL) and Resource Dynamics Corporation (RDC) first examined the optimal locations for deployment of new CHP systems in California. The team used ORNL's Industrial Geospatial Analysis Tool for Energy Evaluation (IGATE-E) to estimate electrical loads at more than 24,000 manufacturing sites within the state, and then calibrated these loads using data from the California Energy Commission. RDC then used its DIStributed Power Economic Rationale SElection (DISPERSE) model to identify economically viable sites for CHP systems at sites with over $100 \mathrm{~kW}$ of electrical load. The National Renewable Energy Laboratory (NREL) then used PLEXOS to analyze the impacts adding CHP at those sites would have on the grid. More detail on each of these steps is provided in the remainder of Section 2.

\subsection{PLEXOS BACKGROUND}

The commercial production cost model PLEXOS optimized operation of the generators to meet load while minimizing overall production cost and observing various constraints, such as generator heat rates 
and operating costs, reserve requirements, and transmission limits. PLEXOS was used to optimize the entire year 2024 of power system day-ahead unit commitment. The NREL California Low Carbon Grid Study (LCGS) data set was used as the Reference scenario for this analysis. ${ }^{17}$ The model was executed using PLEXOS version 7.400 R02.

\subsection{MODELING APPROACH}

This study examined the operation of the California electric grid in 2024 with and without additional CHP deployed at industrial and commercial sites. Four scenarios were evaluated in the California model: Reference or baseload, Traditional CHP, Advanced CHP, and Combined (Table 5). The Traditional, Advanced, and Combined scenarios contain about 1400 more CHP sites in California than the Reference scenario because those sites were assumed to not have CHP in the Reference Scenario's source.

Table 5. Descriptions of California modeling scenarios.

\begin{tabular}{|l|l|}
\hline \multicolumn{1}{|c|}{ Scenario } & \multicolumn{1}{c|}{ Description } \\
\hline Reference & California grid if no additional CHP is added; data sourced from Low Carbon Grid Study \\
\hline ICF data were used to identify the sites where traditional CHP technology would be cost-effectively implemented \\
\hline Traditional & $\begin{array}{l}\text { Grid modeled for all locations where Traditional CHP is economically viable to deploy } \\
\text { Traditional units are constrained to operate no more than } 500 \text { hours per year }\end{array}$ \\
\hline Advanced & $\begin{array}{l}\text { Grid modeled so that Advanced CHP units are deployed, where economically viable. Advanced } \\
\text { CHP is deployed noting that } \\
\text { The Advanced CHP units have higher up-front capital costs than the traditional units } \\
\text { - Advanced CHP provides more grid flexibility and capacity for grid support, so for this } \\
\text { scenario the CHP owner is not choosing the most economical option } \\
\text { The grid modeling determines the value each site owner would obtain from deploying } \\
\text { Advanced CHP units and the associated return on investment, as well as the benefit the grid } \\
\text { would derive from having Advanced CHP units available to support the grid }\end{array}$ \\
\hline Combined & $\begin{array}{l}\text { Grid modeled so that at all locations where either Traditional or Advanced CHP is viable, the } \\
\text { site would choose either Traditional CHP or Advanced CHP, depending on which one is most } \\
\text { economically viable } \\
\text { The Advanced CHP units were noted to be economically viable for installations over } 5 \text { MW } \\
\text { in CHP capacity } \\
\text { Traditional CHP was found to be more economically viable for sites under } 5 \text { MW } \\
\text { What was not known was the impact on grid support costs from having a combination of } \\
\text { both Traditional and Advanced CHP units available for grid support } \\
\text { The grid modeling then determined not only the value each site owner would obtain from } \\
\text { deploying either Traditional or Advanced CHP units and the associated return on } \\
\text { investment, but also the benefit the grid would derive from having a mix of Traditional and } \\
\text { Advanced CHP units available to support the grid }\end{array}$ \\
\hline
\end{tabular}

The LCGS (the basis of the Reference scenario) includes a conservative estimate of $28 \%$ variable renewable generation and 33\% total renewable generation, thus meeting California's intermediate renewable portfolio standard (RPS) requirement. ${ }^{15}$ Although four reserve products are in the California ISO (CAISO) market, the PLEXOS model included two general types of reserves: contingency and regulation. ${ }^{18}$ Contingency reserves refer to the holding of generator capacity for use during generator or

\footnotetext{
${ }^{17}$ G. Brinkman, J. Jorgenson, A. Ehlen, and J. H. Caldwell. Low Carbon Grid Study: Analysis of a 50\% Emission Reduction in California, NREL/TP-6A20-64884, January 2016, accessed at nrel.gov/docs/fy16osti/64884.pdf.

${ }^{18}$ California ISO. Business Practice Manual for Market Operations. February 2, 2017.
} 
transmission outages. Regulation reserves are used to balance small differences between projections and actual demand (load), actual variable renewable generation, and actual generator dispatch.

This modeling effort used the same PLEXOS data set as that used in the LCGS as a starting point for the analysis. ${ }^{19}$ As of December 2016, the state had 8,609 MW of CHP capacity installed. ${ }^{20}$ In PLEXOS, the Reference scenario conformed to the LCGS. The 3,400 MW of existing California CHP units providing grid services (using up to $10 \%$ of their capacity) are categorized as generation that is dispatched within PLEXOS. The remaining 5,209 MW serve site loads exclusively; therefore, the LCGS database includes them as load reduction.

Potential CHP sites were identified using a California Energy Commission study on CHP potential in the state. ${ }^{21}$ Suitable sites were added to a list of sites for evaluation in PLEXOS modeling runs to test the impact of deploying Traditional CHP units, Advanced CHP units, or a combination thereof at the identified sites. To accommodate PLEXOS modeling constraints, the identified CHP sites were geographically consolidated depending on the site size and the corresponding CHP unit's performance characteristics and heat rate. The general modeling flow for the CHP deployment scenarios is shown in Error! Reference source not found.

${ }^{19}$ J. H. Nelson and L. M. Wisland. “Achieving 50 Percent Renewable Electricity in California," Union of Concerned Scientists, 2015, accessed at https://www.ucsusa.org/sites/default/files/attach/2015/08/Achieving-50-PercentRenewable-Electricity-In-California.pdf.

20 "U.S. DOE Combined Heat and Power Installation Database." US Department of Energy, Office of Energy Efficiency and Renewable Energy, accessed at https://doe.icfwebservices.com/chpdb/, accessed December 31, 2016.

${ }^{21}$ B. Hedman, E. Wong, K. Darrow et al. Combined Heat and Power: Policy Analysis and 2011-2030 Market Assessment, ICF International, June 2012. Note: ICF updated the data to include CHP sites included after 2012 and removed any that had been shut down. 


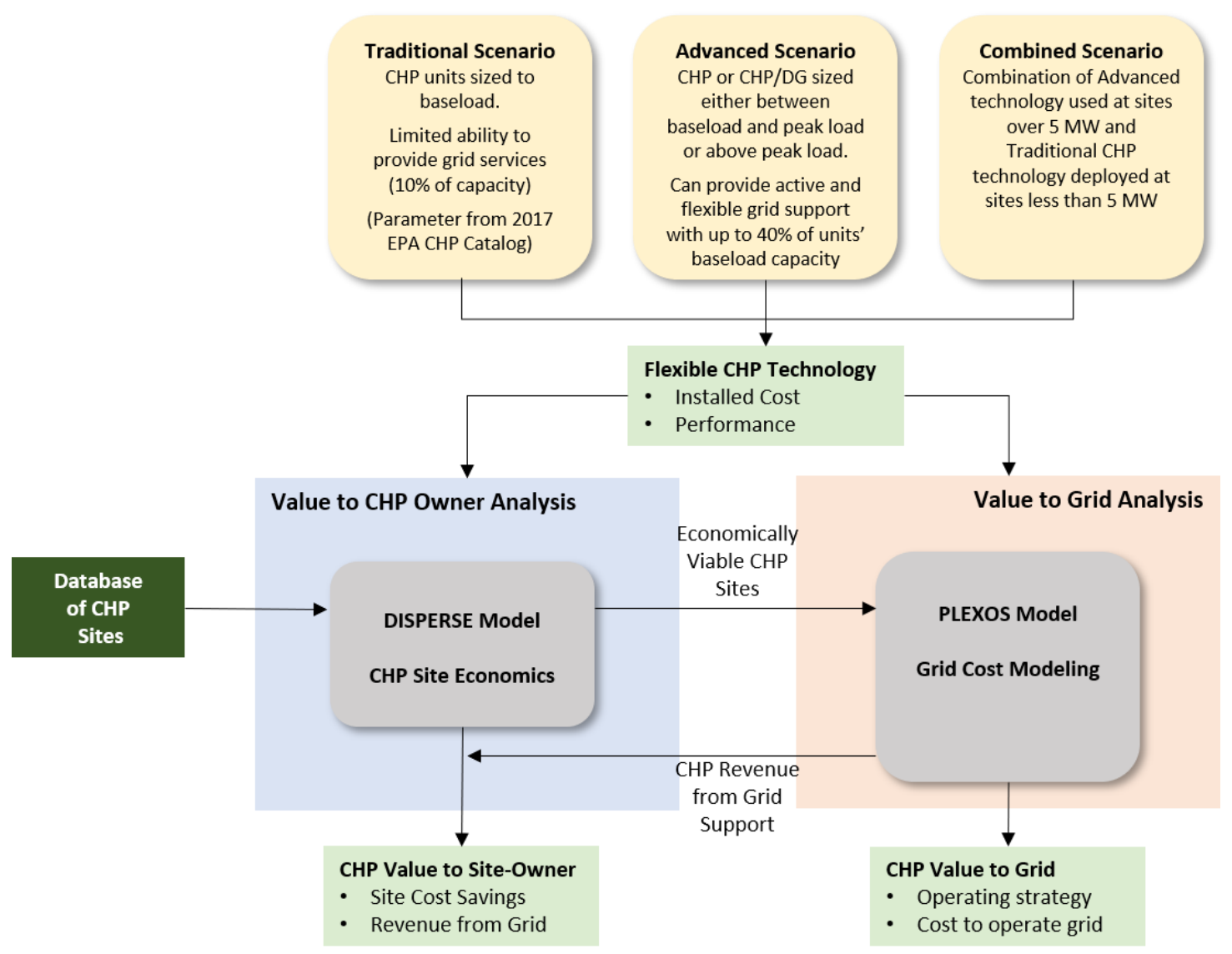

Figure 2. Flow chart depicting PLEXOS modeling runs for the Traditional, Advanced, and Combined scenarios.

To commence the CHP analysis, RDC employed its DISPERSE model ${ }^{22}$ to estimate the economic potential for CHP systems at the California sites. The model estimates the lifecycle cost of deploying and operating a CHP system, and compares that cost with the cost of purchasing electricity and generating heat on-site using natural gas. ${ }^{23}$ To forecast electric rates in 2024, RDC reviewed proposed rate increases from California utilities and academic sources, then applied an annual escalation of $3.7 \%$ to existing tariffs. ${ }^{24}$ The DISPERSE analysis was performed for each of the 1,409 sites to establish initial economic potential, using traditional CHP technology but with installation and maintenance costs escalated to 2024 . The initial economic potential was based on installing CHP at sites that exhibited payback periods of less

${ }^{22}$ Lemar Horne et. al. "Air Quality Impacts of Projections of Natural Gas-Fired Distributed Generation," Atmospheric Environment 168, 8-22, 2017.

${ }^{23}$ Industrial retail natural gas rates for the Traditional and Flexible CHP scenarios were obtained by adding $\$ 1 / M M B T U$ to the utility gas prices used by NREL in the baseline scenario. Utility gas prices in the baseline scenario were obtained from G. Brinkman, J. Jorgenson, A. Ehlen, and J. H. Caldwell. Low Carbon Grid Study: Analysis of a 50\% Emission Reduction in California, NREL/TP-6A20-64884. January 2016.

${ }^{24}$ Forecasted annual increases in electricity prices for California range from 1.9 to $6.3 \%$ in J. Cook, A. Smidebush, and S. Gunda. The Future of Electricity Prices in California: Understanding Market Drivers and Forecasting Prices to 2040, University of California-Davis Energy Efficiency Center, December 2013. In addition, Los Angeles Department of Water and Power projected its 2015-2020 rates for large commercial/industrial customers would increase by $3.7 \%$ per year (www.myladwp.com/2016_2020_rate_request). 
than 10 years, with the goal of reaching under 6 years when the economic benefits of providing grid support were incorporated in the analysis. The payback calculations did not include capital cost reductions from the federal Business Energy Investment Tax Credit or incentive payments from California's Self Generation Incentive Program, as the economic climate of 2024 may not maintain such programs.

As shown in Figure 2, the modeling process was iterative, as it involved first determining whether the CHP systems were economical, considering the cost of installation of Traditional CHP options and the economic benefits of its operation to the host site. The initial economic evaluation considered only the benefits to the site in terms of displacing electricity purchases and fuel for producing thermal output. The additional value of grid support was not yet known, but it was expected to provide some additional revenue and therefore some reduction in payback period. Thus, it was decided that sites with longer paybacks (6 to 10 years) would not be eliminated until the impact of grid support was ascertained. Under the 2024 economic conditions modeled, the calculated payback period for none of the 1,409 sites is longer than 10 years for traditional CHP technology. Therefore, even though they might be too expensive for the owner to invest in the CHP units, those sites have sufficient economic potential to include in this analysis because additional revenue for providing grid support may meet investment criteria. Section 2.3 provides results and more information on the potential for grid support to reduce payback periods.

These sites were then evaluated as potential grid resources in PLEXOS modeling runs, to simulate the impact of deploying Traditional CHP units, Advanced CHP units, or a combination thereof at the identified sites. To accommodate PLEXOS modeling constraints, the identified CHP sites were geographically consolidated depending on the site size and the corresponding CHP unit's performance characteristics and heat rate. The PLEXOS model was then run to simulate when the CHP units were dispatched. Then the initial PLEXOS grid support revenues earned by the CHP sites were aggregated and used to refine the CHP analysis.

After the PLEXOS model results became available, the grid support revenues were added to the cost savings the site realized from CHP to develop a total annual cost benefit value. The total installed cost was divided by this value to determine the payback period. This process was repeated for the Traditional scenario and the Advanced scenario, with the key difference being the CHP technology cost and performance assumptions that are being evaluated. Advanced CHP projects were assumed to have a 10year lifetime starting in 2024. In addition, the grid support revenues were enhanced when assumptions of capacity payments were made. The analysis considered capacity payments based both on current levels of about $\$ 20$ per $\mathrm{kW}^{25}$ annually, and on a long-term planning cost basis ${ }^{26}$ of about $\$ 100$ per $\mathrm{kW}$ annually. Collectively, the grid support revenues were combined with site cost reductions to determine whether the site owner would be expected to proceed with CHP investment based on payback.

In the Traditional scenario, all but one site exhibited paybacks of under 6 years when long-term capacity payments were reflected in grid support revenues. In the Advanced scenario, a higher installed cost led to more sites having longer payback periods, although it was noted that the 465 sites with payback periods over 6 years all had CHP units of less than 5 MW. As a result, a Combination scenario was developed which applied advanced CHP at sites with CHP units of over $5 \mathrm{MW}$ and traditional CHP at smaller sites. This reduced the number of sites with payback periods of over 6 years to one site again; however, it

\footnotetext{
${ }^{25} \mathrm{~A}$ payment of $\$ 20 / \mathrm{KW}$ per year is approximately equal to the CAISO system average resource adequacy contract price for the year 2017. This statistic is taken from the California Public Utilities Commission's 2017 Resource Adequacy Report.

${ }^{26}$ S. A. Newell. Fourth Review of PJM's Variable Resource Requirement Curve, The Brattle Group, April 19, 2018. Values for the 2022/2023 gross CONE of $\$ 104 / \mathrm{kW}$-year for combustion turbine is taken from Table ES-1.
} 
incorporated the grid support benefits of advanced CHP for the larger sites. The overall impact on the grid is discussed in the next section.

The general modeling flow for the CHP deployment scenarios is shown in Figure 2. The detailed CHP cost and performance data employed in the analysis are shown in detail in Appendix C.

Advanced and flexible CHP has some unique characteristics that could enable it to develop a niche within energy markets. As shown in Table 6, coal/nuclear and biomass, and even larger central station renewables such as concentrated solar power or geothermal, have a low generation cost; so they are used as baseload and generate power across all time periods. In the Reference scenario, the load was at least $35 \mathrm{GW}$ during $99 \%$ of the hours each year, so the baseload and the most efficient combined-cycle options competed to provide round-the-clock generation. Combined-cycle and combustion turbine generators have higher generation costs but are more flexible (i.e., they can be turned up and down or on and off), so they are intermediate or peaking generators. Therefore, their startup costs become important in considering their cost to the grid. If they can operate for 6 or more continuous hours, they are competitive as intermediate cycling generators. However, advanced CHP units can compete against them because the CHP units have no appreciable startup costs (as the units are already operating and just need to be ramped up to meet additional loads), especially when the intermediate cycle periods are limited. For these reasons, the PLEXOS modeling dispatched the advanced CHP units for 6,000 hours or more in several of the California regions. 
Table 6. Dispatch stack of weighted average cost to generate. ${ }^{27}$

\begin{tabular}{|c|c|c|c|}
\hline Type of generator/fuel & $\begin{array}{l}\text { A verage variable cost } \\
\text { to generate (\$/MWh) }\end{array}$ & $\begin{array}{l}\text { Typical duration } \\
\text { of cycle }\end{array}$ & Startup cost (\$/MW) \\
\hline Central station renewables & 7.5 & Baseload & $\mathrm{NA}$ \\
\hline Baseload steam-coal/nuclear & 16.0 & Baseload & NA \\
\hline Baseload steam-biomass & 27.9 & Baseload & $\mathrm{NA}$ \\
\hline Combined-cycle gas-single shaft & 31.4 & Intermediate & 84 \\
\hline Combined-cycle gas-multi shaft & 35.6 & Intermediate & 84 \\
\hline Combustion turbine-natural gas & 37.7 & $\begin{array}{l}\text { Intermediate } \\
\text { /peaking }\end{array}$ & 84 \\
\hline Steam turbine-natural gas & 49.3 & $\begin{array}{l}\text { Intermediate } \\
\text { /peaking }\end{array}$ & 84 \\
\hline Advanced CHP-natural gas & 49.8 & $\begin{array}{l}\text { Intermediate } \\
\text { /peaking }\end{array}$ & 0 \\
\hline
\end{tabular}

As an illustration of why flexible CHP units are cost-competitive, Figure 3 examines a 24 hour period in the Pacific Gas and Electric zone in August 2019. There is a short 3 hour period of prices over \$50/MWh; but for the rest of the day, the prices are lower. For this day, even though combined-cycle units had lower variable costs of generation than Advanced CHP units, their ability to take advantage of the higher-price periods was constrained by their startup cost. For example, in Figure 3, there are 6 hours during which locational marginal prices are higher than the combined-cycle single-shaft unit's variable operating cost $(\$ 31.4 / \mathrm{MWh})$. However, the units' startup costs of $\$ 84 / \mathrm{MW}$ would have to be spread over those 6 hours. Thus, their total cost to generate is $\$ 31.4 / \mathrm{MWh}+(\$ 84 / \mathrm{MW} / 6 \mathrm{~h})=\$ 45.4 / \mathrm{MWh}$. Since there are only 5 (hours 17-21) during which prices are over $\$ 45.4 / \mathrm{MWh}$, the total cost to generate for those 5 hours would be $\$ 48.2 / \mathrm{MWh}$, but there are only 4 hours during which prices are over this rate (hours 18-21). Combined cycle units have the same economic challenges when operating for 4 hours, with a cost of $\$ 52.4 / \mathrm{MWh}$; the same is true for 3 hours of operation. When a 3 hour period was considered, the startup cost became more prohibitive, as the total cost for combined-cycle units to generate became $\$ 59.4 / \mathrm{MWh}$. With a total cost to generate of $\$ 49.8 / \mathrm{MWh}$, the cost of operating advanced CHP units was lower than the cost for combined-cycle units, and Advanced CHP was more likely to be dispatched. The modeling results for an entire year (see Table 7) found that the Advanced CHP technology would be used over 45,000 unithours/year, which is 15 times greater than the 3,418 unit-hours/year the Traditional CHP technology would be used.

\footnotetext{
${ }^{27}$ Based on weighted averages of the California fleet from the California Low Carbon Grid Study.Error! Bookmark not defined.
} 


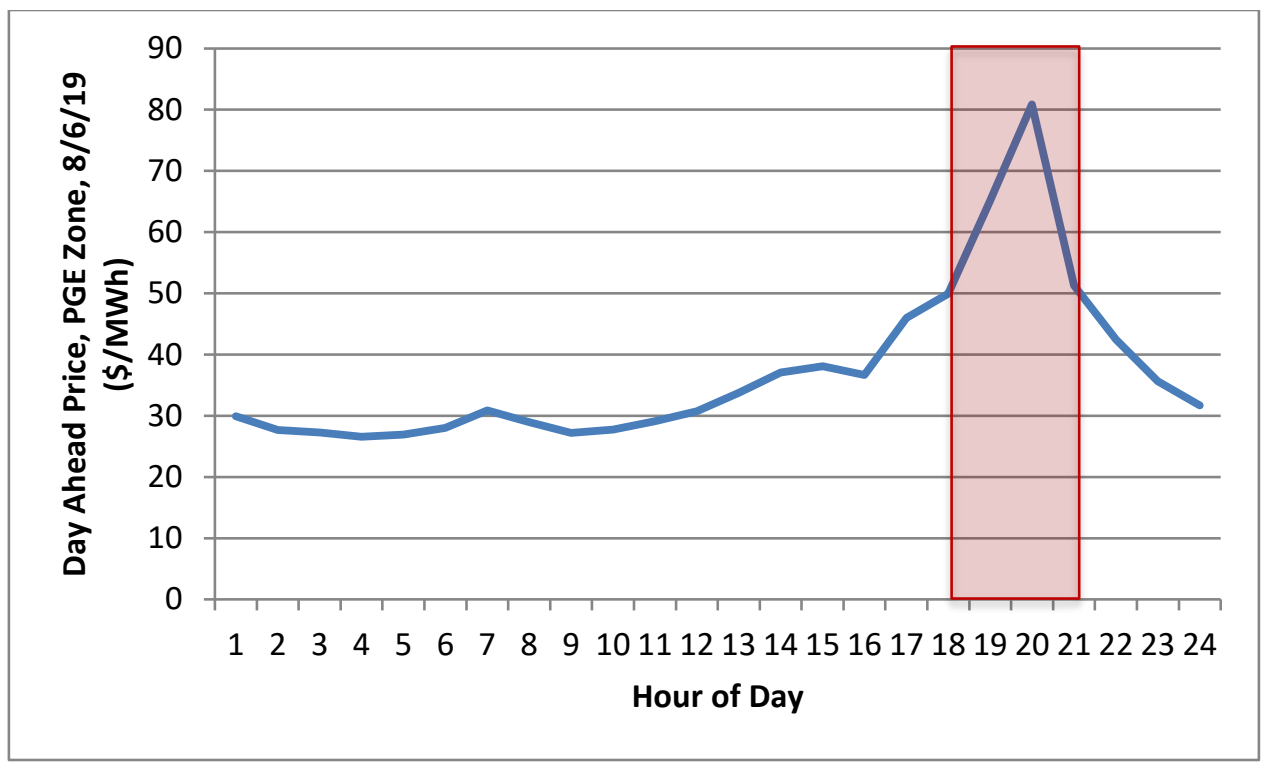

Figure 3. California independent system operator day-ahead price, August 6, 2019.

\subsection{CHP VALUE TO SITE OWNER}

To realize the potential benefits of CHP to the grid, potential CHP site owners must obtain some value, economic or otherwise, that provides a sufficiently substantial incentive for them to deploy the units. Figure provides a comparison of the average site payback in years for the CHP units by size category. Payback periods are determined by dividing the installed cost of the system by the total savings to the owner. The total savings to the owner is defined as reductions in grid purchases and boiler fuel costs plus grid support revenue costs, minus CHP fuel costs, standby costs, and operations and maintenance cost.

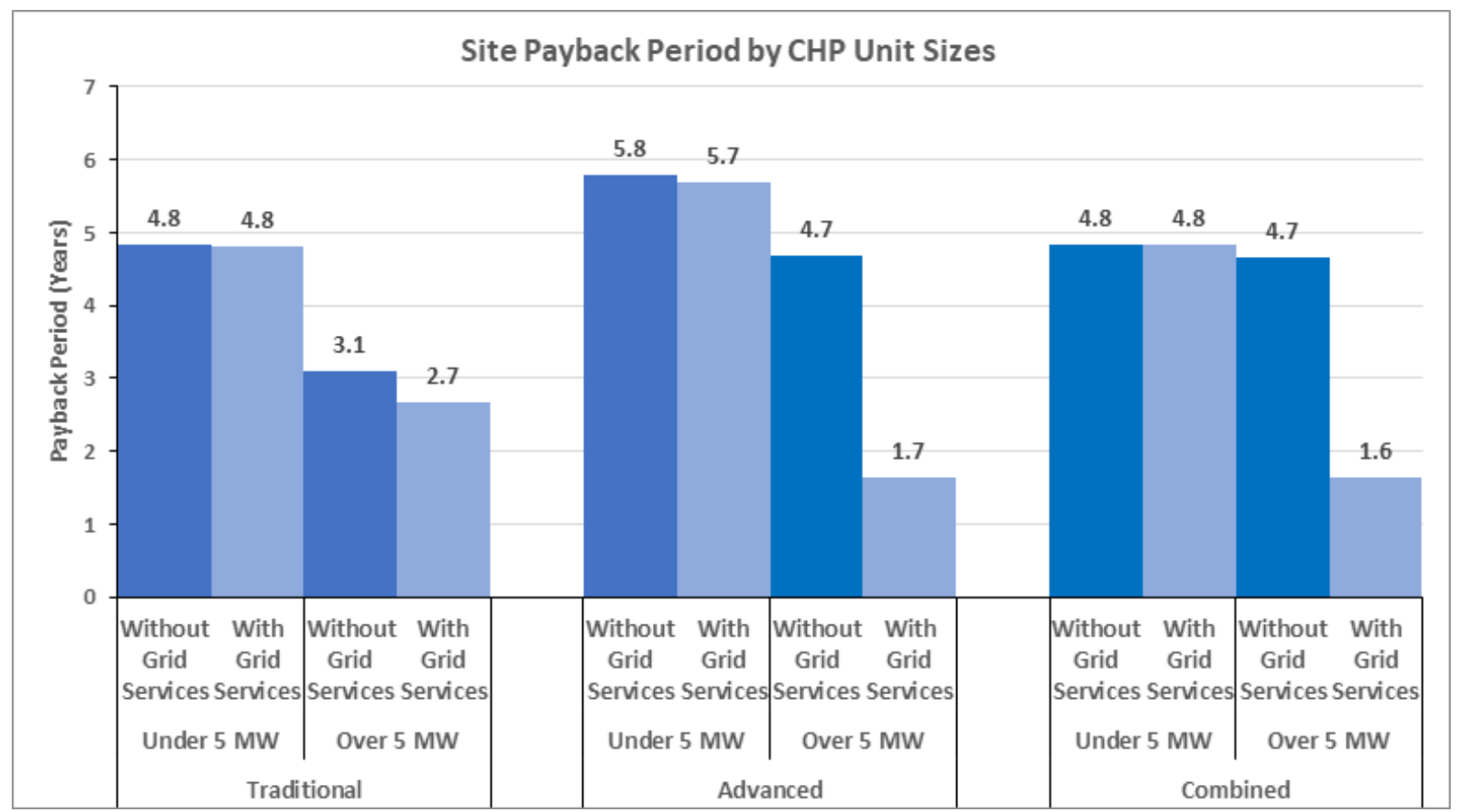

Figure 4. Average site payback periods for CHP units over and under 5 MW for Traditional, Advanced, and Combined scenarios (payback periods do not include capacity payments). 
Table 7 compares the value to the grid that is attributable to surplus CHP capacity earned from either energy production or participation in ancillary service markets for CHP site owners. In this analysis, the revenue earned by CHP owners is assumed to be the PLEXOS estimate of grid cost reductions provided by the surplus CHP capacity - in other words, the grid cost reduction is passed on to the CHP owners. In the Traditional scenario, site owners would benefit most from earning revenues attributed to ancillary services (\$13 million of \$14 million). In the Advanced scenario, larger CHP units (5+ MW) had a very competitive heat rate during surplus operation and were no longer constrained by annual hours of operation. The larger Advanced units showed a dramatic increase in utilization and value through participation in energy markets, producing nearly $\$ 760$ million in annual revenue and accounting for about $\$ 950,000$ in revenue per megawatt of surplus capacity for site owners. However, the smaller units that were viable in the Traditional scenario did not provide a sufficiently rapid return on investment for site owners to justify the additional investment required in the Advanced scenario. The Combined scenario accounted for these nonviable units by selecting all the economically viable CHP units from the Advanced scenario (all of which were greater than $5 \mathrm{MW}$ ) for deployment, and then modeling the remaining sites deploying Traditional CHP technology.

Table 7. Summary of annual energy and ancillary service revenues (surplus only) by scenario and scale. ${ }^{28}$

\begin{tabular}{|c|c|c|c|c|c|c|}
\hline \multirow[b]{2}{*}{ Scenario and scale } & \multicolumn{3}{|c|}{ Revenue (\$K/year) } & \multirow{2}{*}{$\begin{array}{c}\text { Hours } \\
\text { operating at } \\
\text { surplus per } \\
\text { year }\end{array}$} & \multirow{2}{*}{$\begin{array}{l}\text { Surplus } \\
\text { capacity } \\
\text { (MW) }\end{array}$} & \multirow{2}{*}{$\begin{array}{c}\text { Revenue } \\
\text { (\$K/year per } \\
\text { MW surplus) }\end{array}$} \\
\hline & Energy & $\begin{array}{l}\text { Ancillary } \\
\text { service }\end{array}$ & Total & & & \\
\hline Traditional & $\$ 1,182$ & $\$ 12,820$ & $\$ 14,002$ & 3,418 & 358 & $\$ 39$ \\
\hline 5+ MW (T6040) & $\$ 1,059$ & $\$ 9,336$ & $\$ 10,394$ & 2,964 & 165 & $\$ 63$ \\
\hline 1-5 MW (T6080) & $\$ 121$ & $\$ 3,175$ & $\$ 3,296$ & 333 & 172 & $\$ 19$ \\
\hline Under 1 MW (T6815) & $\$ 2$ & $\$ 309$ & $\$ 312$ & 121 & 21 & $\$ 15$ \\
\hline Advanced & $\$ 759,303$ & $\$ 13,212$ & $\$ 772,515$ & 45,696 & 1,324 & $\$ 583$ \\
\hline 5+ MW (A4900) & $\$ 759,144$ & $\$ 8972$ & $\$ 768,116$ & 45,269 & 808 & $\$ 951$ \\
\hline 2-5 MW (A6540) & $\$ 122$ & $\$ 2077$ & $\$ 2,199$ & 205 & 258 & $\$ 9$ \\
\hline Under 2 MW (A6800) & $\$ 37$ & $\$ 2,163$ & $\$ 2,200$ & 222 & 262 & $\$ 9$ \\
\hline Combined & $\$ 763,828$ & $\$ 16,934$ & $\$ 780,762$ & 45,180 & 1,000 & $\$ 781$ \\
\hline 5+ MW (A4900) & $\$ 763,737$ & $\$ 14,805$ & $\$ 778,543$ & 44,689 & 799 & $\$ 974$ \\
\hline 5+ MW (T6040) & $\$ 4$ & $\$ 0$ & $\$ 4$ & 135 & 1 & $\$ 3$ \\
\hline 1-5 MW (T6080) & $\$ 83$ & $\$ 1,922$ & $\$ 2,006$ & 232 & 179 & $\$ 11$ \\
\hline Under 1 MW (T6815) & $\$ 3$ & $\$ 206$ & $\$ 209$ & 124 & 21 & $\$ 10$ \\
\hline $0-2 \mathrm{MW}(\mathrm{MT})$ & $\mathrm{n} / \mathrm{a}$ & $\mathrm{n} / \mathrm{a}$ & $\mathrm{n} / \mathrm{a}$ & $\mathrm{n} / \mathrm{a}$ & $\mathrm{n} / \mathrm{a}$ & $\mathrm{n} / \mathrm{a}$ \\
\hline
\end{tabular}

Note: Numbers in parentheses represent the heat-rate of the CHP unit. T, A and MT in parentheses represent Traditional, Advanced, and Microturbines, respectively.

Additional advancements are needed to make the smaller CHP units economically viable for deployment at industrial and commercial sites. Some facilities may choose to deploy CHP systems to increase the resilience of a site, or to allow for greater energy independence. However, there are currently insufficient incentives to choose a CHP option with surplus capacity that can be used to support the grid.

\footnotetext{
${ }^{28}$ Additional information on the equations used to produce revenue data are included in Appendix A
} 


\subsubsection{Potential Revenue Stream from Capacity Payments}

CAISO does not operate a centralized capacity market such as the ones operated by its East Coast counterparts (PJM Interconnection, New York ISO, ISO-New England). Instead, resource adequacy requirements are handled by load serving entities (LSEs) such as independently owned utilities and electric service providers, mostly through bilateral contracts and self-supply. Industrial and commercial sites could be more incentivized to install CHP units if CAISO were to adopt a capacity market.

Figure 4 shows the improvement in average payback period for site owners that is realized through the incorporation of grid revenues and then by the addition of capacity payments. The two scenarios with capacity payments assume additional revenues of $\$ 20 / \mathrm{kW}$-year and $\$ 100 / \mathrm{kW}$-year. Revenue of $\$ 100 / \mathrm{kW}$ year is approximately equal to the levelized cost of new entry (CONE) of a natural gas-fired combustion turbine within the PJM market. ${ }^{29}$ The CONE represents the total annual net revenue that a generation unit would need to recover its capital investments and fixed costs. Revenue of $\$ 100 / \mathrm{kW}$-year also fits within the range of resource adequacy payments received by generators within CAISO to cover their fixed costs. ${ }^{30}$ Therefore, if CAISO were to implement a capacity market, a CONE of approximately $\$ 100 / \mathrm{kW}$ year would be a reasonable estimate, Table 8 shows the capacity payments to site owners by scenario at $\$ 20 / \mathrm{kW}$-year and at $\$ 100 / \mathrm{kW}$-year.

Table 8. Capacity payments by scenario

\begin{tabular}{|c|c|c|}
\hline Scenario & $\begin{array}{c}\text { Capacity payment } \\
(\$ 20 / \mathrm{kW} \text {-year }) \\
\$ K\end{array}$ & $\begin{array}{c}\text { Capacity paymen } \\
\text { (\$100/kW-year) } \\
\$ \text { K }\end{array}$ \\
\hline Traditional & $\$ 149,320$ & $\$ 746,600$ \\
\hline Advanced & $\$ 168,640$ & $\$ 843,200$ \\
\hline Combined & $\$ 162,160$ & $\$ 810,800$ \\
\hline
\end{tabular}

Figure 5 shows that grid revenues and capacity payments shorten the payback period for all types of units. Units of more than $5 \mathrm{MW}$ capacity saw a significant shift when grid revenues were considered over an average payback period of 1.65 years rather than 4.68 years. Capacity payments had less effect on improving the economics of 5+ MW units and decreased payback periods by only an additional 6\%. This contrasted with results for units of less than $5 \mathrm{MW}$ capacity, which had their average payback periods reduced by over $15 \%$ when capacity payments were considered. These payments therefore represent one way to increase the economic viability of smaller CHP units.

\footnotetext{
${ }^{29}$ S. A. Newell, et al. PJM Cost of New Entry, Combustion Turbine and Combined Cycle Plants with June 1, 2022 Online Date, s.l., The Brattle Group, 2018.

${ }^{30}$ L. Chow and S. Brant. The 2017 Resource Adequacy Report, California Public Utilities Commission, August 2018.
} 


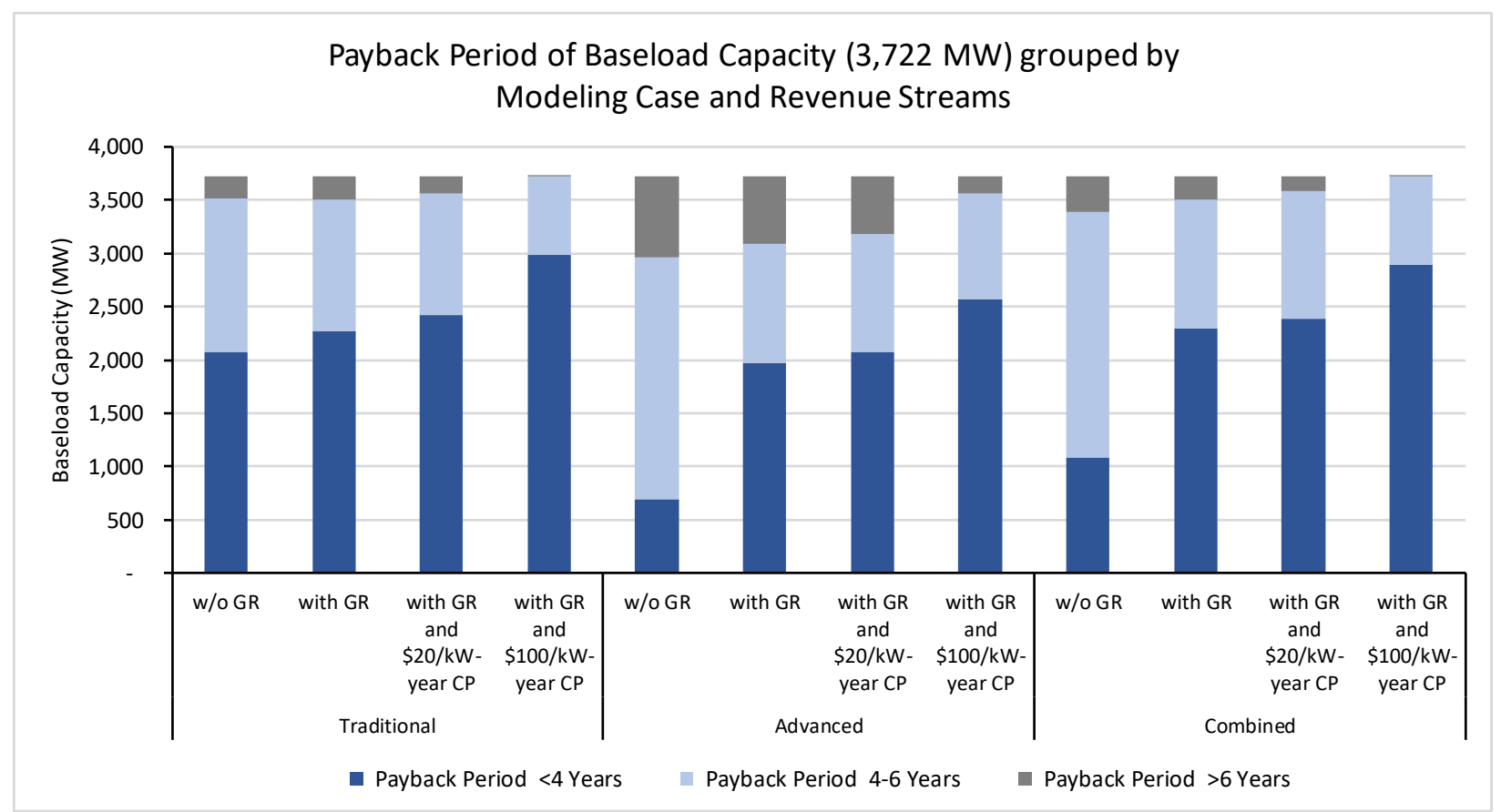

Figure 5. The effects of payback periods for Advanced CHP units. grid revenues (GR), and capacity payments (CP) on the payback period are compared (further details are available in Appendix B).

\subsection{CHP CAPACITY BY REGION}

Figure 6 and Table 9 show the currently installed CHP capacity as it exists in the Reference scenario, with the potential CHP capacity for the Traditional, Advanced, and Combined scenarios also aggregated by region. While all modeled utility regions saw increases in CHP capacity in the Traditional, Advanced, and Combined scenarios, Southern California Edison (SCE) had by far the biggest increase in maximum CHP capacity across all models, primarily because of an increase in electrical load in the region. In the SCE region, generation by CHP units in the Traditional, Advanced, and Combined scenarios offset a large amount of energy typically imported into southern California. The increase in CHP capacity in other regions mostly represented a switch from other combustion technologies to CHP units. 


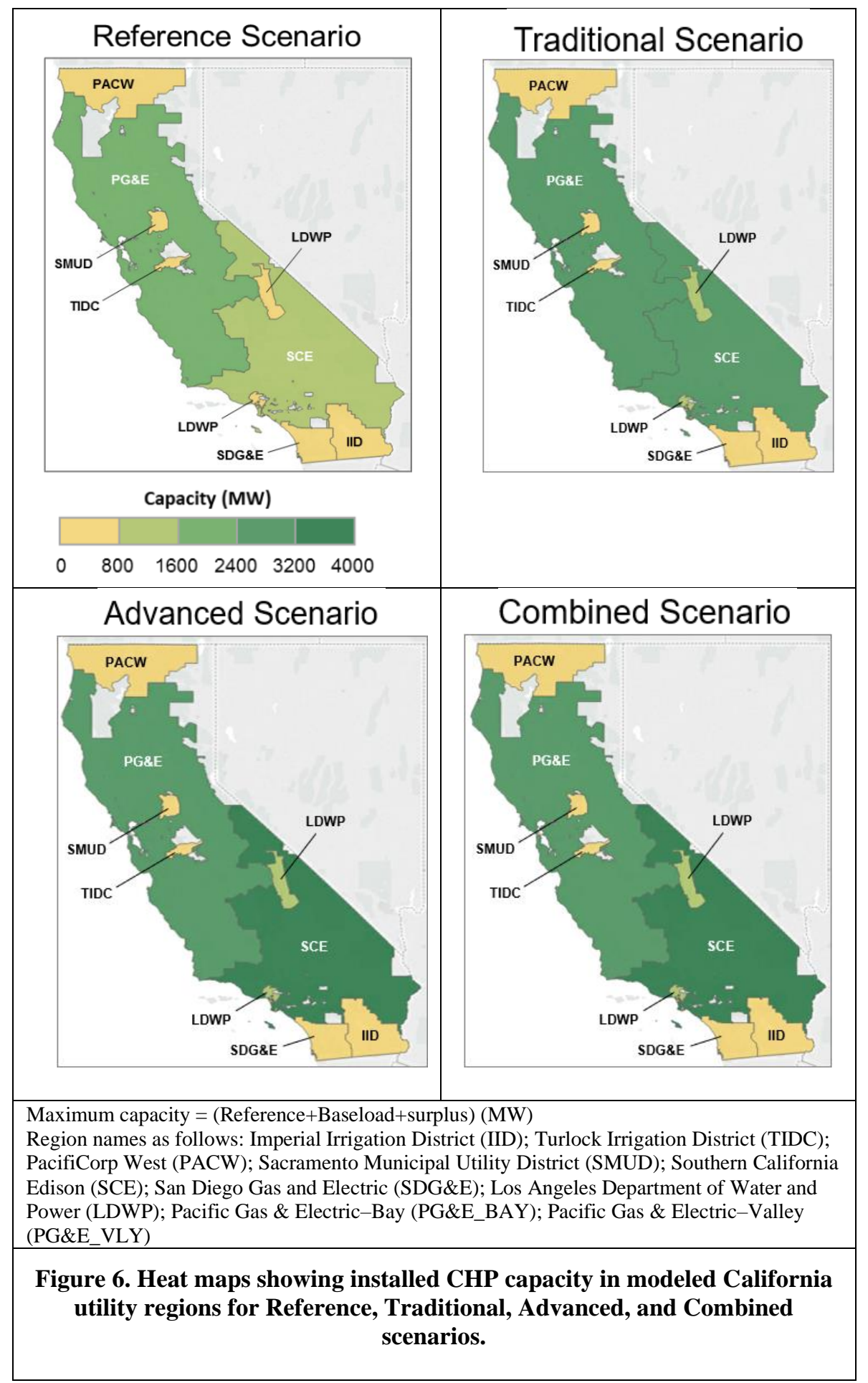


Table 9. Maximum CHP capacity and number of sites by region for each California modeled scenario.

\begin{tabular}{|l|r|r|r|r|r|}
\hline \multicolumn{1}{|c|}{ Region } & $\begin{array}{c}\text { Reference } \\
\text { capacity } \\
\text { (MW) }\end{array}$ & Model sites & $\begin{array}{c}\text { Traditional } \\
\text { max capacity } \\
\text { (MW) }\end{array}$ & $\begin{array}{c}\text { Advanced max } \\
\text { capacity } \\
\text { (MW) }\end{array}$ & $\begin{array}{c}\text { Combined max } \\
\text { capacity } \\
\text { (MW) }\end{array}$ \\
\hline IID & - & 6 & 17 & 25 & 24 \\
\hline TIDC & - & 12 & 36 & 46 & 42 \\
\hline PACW & - & 12 & 25 & 34 & 25 \\
\hline SMUD & 70 & 102 & 354 & 418 & 393 \\
\hline SCE & 1,053 & 641 & 2,987 & 3,442 & 3,292 \\
\hline SDG\&E & 47 & 119 & 365 & 429 & 404 \\
\hline LDWP & 562 & 72 & 840 & 909 & 891 \\
\hline PG\&E_BAY & 449 & 241 & 1,064 & 1,205 & 1,152 \\
\hline PG\&E_VLY & 1,203 & 204 & 1,778 & 1,924 & 1,883 \\
\hline Total & $\mathbf{3 , 3 8 5}$ & $\mathbf{1 , 4 0 9}$ & $\mathbf{7 , 4 6 6}$ & $\mathbf{8 , 4 3 2}$ & $\mathbf{8 , 1 0 8}$ \\
\hline
\end{tabular}

\subsection{CHP VALUE TO GRID}

The analysis quantified the value CHP can add to the grid across several factors. The model calculated the grid's overall operating costs, including the costs for emissions, fuel, startup and shutdown, variable operations and maintenance (VO\&M), reserve, and net imports. Additionally, the model calculated revenues from the surplus capacity of CHP units attributable to energy sales and ancillary services. The values in the Reference scenario were calculated by running PLEXOS using the generation fleet reported in the LCGS. ${ }^{17}$ The revenues from the surplus capacity are the key economic driver to incentivize a potential site owner to install a CHP system.

Adding CHP to California's generation fleet could reduce the overall cost of meeting the state's electrical loads, as shown in Figure. Although VO\&M costs increase in all scenarios, these costs are offset by the reduced need to purchase imported energy, lower emissions costs, and lower fuel costs. The Advanced scenario demonstrates the greatest value to the grid of 6.8\% savings (\$904 million compared with the Reference scenario). The Traditional and Combined scenarios also show significant value to the grid in terms of reducing the overall cost of grid operation. Although all the CHP deployment scenarios demonstrate value to the grid, it is important to understand whether industrial and commercial site owners have an economic incentive to deploy CHP units at their facilities. 


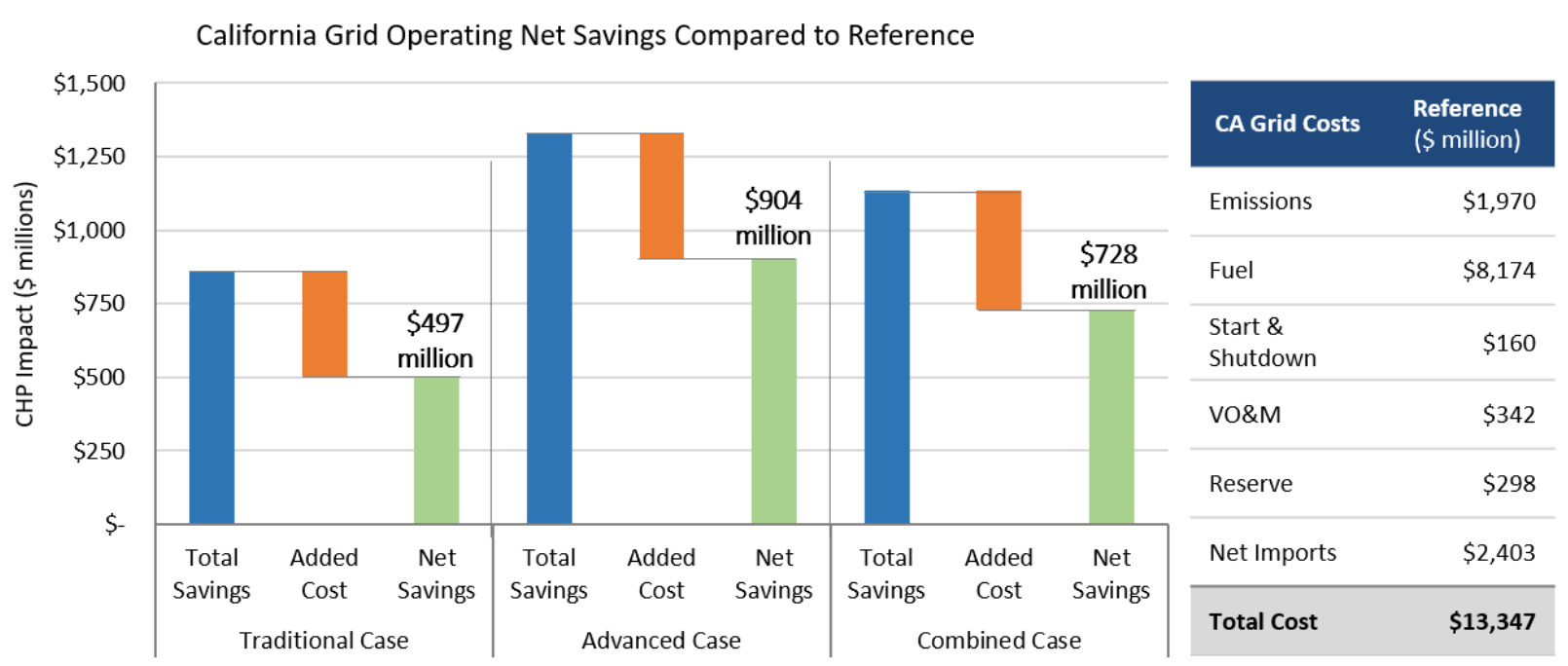

Figure 7. Annual California grid operating cost savings compared with Reference scenario.

\subsection{CHANGES TO GRID GENERATION PROFILES}

Because the additional CHP units serve local site loads and have surplus capacity to provide energy to the grid, CHP in the Traditional, Advanced, and Combined CHP scenarios replaced baseload and peaking assets. Specifically, CHP displaced natural gas combined-cycle units and natural gas combustion turbine units. Figure compares changes in the grid generation profiles for the Traditional, Advanced, and Combined CHP scenarios with the Reference scenario.

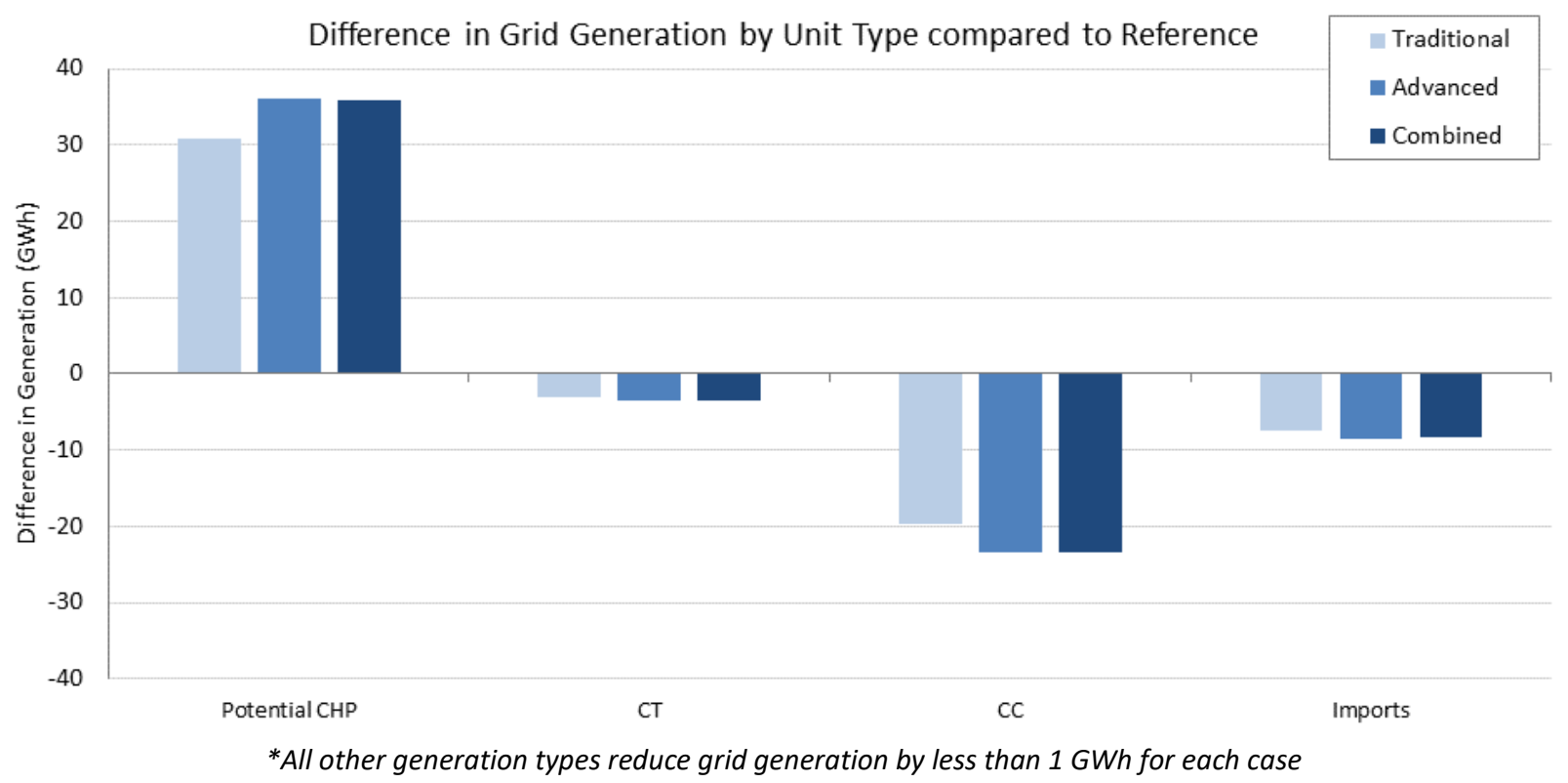

Figure 8. Annual grid generation profile for the Traditional, Advanced, and Combined CHP scenarios relative to the Reference scenario. 
Displacement of combined-cycle units is likely because of the baseload portion of the CHP units' operation. The baseload generation provides electricity for site loads and reduces the total load on California's grid so that fewer combined-cycle units are needed to provide system energy. Combustion turbine units are more typically used for peaking - providing energy during times of high stress and rapid ramping, such as during the evening solar ramp. Displacement of those units was caused primarily by the flexible surplus capacity of the CHP units (although that flexibility is limited, as described in Table 3). Additionally, the further displacement of both combustion turbine and combined-cycle units seen in the Advanced and Combined scenarios compared with the Traditional scenario was due to a further increase in flexible surplus capacity. Presumably, that additional surplus capacity represented even more energy available for times of high stress and rapid ramping.

Although it is not reflected in this model, California's zero-carbon grid generation goal will require solutions to maintain grid stability. CHP units are one tool that can help ensure that the grid remains less stressed and economically efficient, even as higher levels of variable power generation are added.

\subsection{REDUCTIONS IN GRID STRESS}

In this analysis, "grid stress" was defined as periods when energy prices exceed the cost of the most expensive generator, indicating high stress to the grid. Figure shows the grid stress hours measured for the Reference scenario over 1 year. Grid stress is associated with violating the constraints of normal grid operations, such as overloading of transmission lines, failing to provide required reserves, or exceeding generator-rated properties. Although violation of these constraints does not indicate that the grid is in danger of collapse, it does indicate that the system is sufficiently strained that reliability standards for operation cannot be met. In the Traditional, Advanced, and Combined scenarios, CHP systems eliminated grid stress hours in every region of California; however, since grid stress was not costed directly, the savings are not monetized.

Grid Stress Hours

Label: Reference Scenario (Traditional \& Advanced Scenarios)

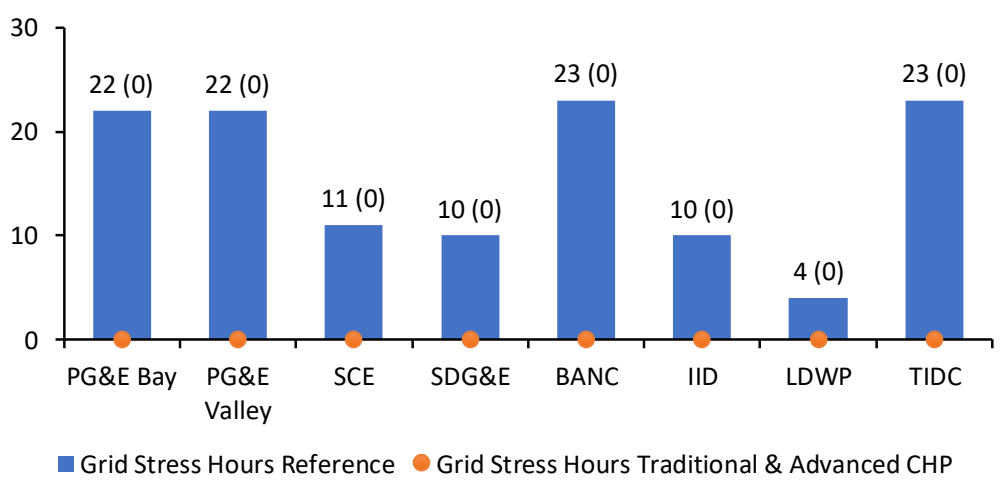

Figure 9. Annual high-stress grid hours by region. 


\section{SUMMARY}

This report identifies key ways in which additional CHP deployment in California could deliver critical benefits to the state's electricity grid. However, this analysis did not look at the potential impacts of other technologies and how they might compete with CHP to provide those services.

This analysis shows that, in addition to California's projected CHP capacity of 3,400 MW, an additional 4,100 to $5000 \mathrm{MW}^{31}$ of CHP capacity could be economically viable for site owners based on advanced CHP technology costs and performance.

The results of the analysis show that development and deployment of advanced, flexible CHP units could generate over $\$ 770$ million in revenue for CHP site owners by using surplus capacity to generate energy that is sent to the grid, allowing them to participate in energy and ancillary service markets. The value to CHP site owners could be amplified if there were methods to compensate CHP owners for the capacity they provide. These capacity market revenues could reach over $\$ 160$ million annually using conservative estimates (refer to the Traditional and Combined scenarios in Table 7). Additionally, although the payback period may already be enough to incentivize the deployment of CHP units of over 5 MW (under 6 years), the inclusion of capacity payments could reduce the average payback period for larger CHP units (over 5MW) from 3 years to under 2 years. Smaller CHP sites - those with less than $5 \mathrm{MW}$ of capacity - showed a marginal reduction in payback with full grid revenues, including capacity payments. Advanced CHP scenarios provided substantial reductions in grid cost; however, without changes in the grid pricing structure, the CHP owner would not realize any of the additional value. Thus, grid incentives directed at encouraging commercial sites to adopt CHP would be beneficial. If technological advances should make CHP more affordable and capable of operating more flexibly, it would be economical to deploy CHP at more industrial and commercial sites throughout California.

The addition of CHP to California's generation fleet could reduce the overall cost of meeting the state's electrical loads by up to 6.8\% (\$904 million annually). CHP units could also eliminate grid stress hours in every modeled region of California. The future grid could then not only rely on flexible CHP units to provide energy during periods when solar generation is dropping off, but also use CHP systems as a source of valuable reserve capacity. CHP systems could displace less efficient sources of generation for both baseload and peaking capacity and could reduce electricity imports into California. Collectively, the results of this analysis indicate that CHP deployment in California warrants additional consideration by grid operators, policy makers, and commercial and industrial sites.

Other regions in the United States could also benefit from advanced CHP systems, in terms of reducing the overall cost of grid electricity supply and stress hours as renewable penetration rises. Additional analysis should be conducted to understand the magnitude of the potential of CHP to enhance resilience and reduce grid congestion in other regions. Although the detailed parameters and market structures for other transmission regions will differ, it is very likely that developing advanced CHP systems would economically achieve substantial penetration into other regions. CHP units would displace less efficient and more costly generators and reduce grid operating costs and stress hours. Thus, advanced CHP would reduce the cost of operating the grid and increase reliability and resilience. Moreover, because market structures may need to evolve to realize the benefits of advanced CHP, it should be considered in supplyside policies as well as demand-side grid planning.

\footnotetext{
${ }^{31}$ See Appendix A, Table A.1.
} 



\section{APPENDIX A. MODELING PARAMETERS AND SOURCES}

Table A.1. Comparison of CHP unit heat rates and capacity by scenario.

\begin{tabular}{|c|c|c|c|c|c|}
\hline \multirow{2}{*}{$\begin{array}{c}\text { Scenario and CHP unit size } \\
\text { grouping }\end{array}$} & \multicolumn{2}{|c|}{ Baseload } & \multicolumn{2}{|c|}{ Surplus } & \multirow{2}{*}{$\begin{array}{l}\text { Additional } \\
\text { capacity }\end{array}$} \\
\hline & $\begin{array}{l}\text { Heat rate } \\
\text { (BTU/kWh) }\end{array}$ & $\begin{array}{l}\text { Capacity } \\
\text { (MW) }\end{array}$ & Heat rate & Capacity & \\
\hline Reference & & 1,855 & & 1,530 & 3,385 \\
\hline Traditional & & 5,578 & & 1,888 & 7,466 \\
\hline $5+\mathrm{MW}$ & 5,300 & 1,655 & 6,040 & 165 & 1,820 \\
\hline $1-5 \mathrm{MW}$ & 5,150 & 1,787 & 6,080 & 172 & 1,959 \\
\hline Under $1 \mathrm{MW}$ & 5,400 & 281 & 6,815 & 21 & 302 \\
\hline Reference & & 1,855 & & 1,530 & 3,385 \\
\hline Advanced & & 5,574 & & 2,858 & 8,432 \\
\hline $5+\mathrm{MW}$ & 5,610 & 1,655 & 4,900 & 808 & 2,463 \\
\hline $2-5 \mathrm{MW}$ & 5,130 & 1,032 & 6,540 & 258 & 1,290 \\
\hline Under $2 \mathrm{MW}$ & 5,680 & 1,032 & 6,800 & 262 & 1,294 \\
\hline Reference & & 1,855 & & 1,530 & 3,385 \\
\hline Combined & & 5,578 & & 2,530 & 8,108 \\
\hline 5+ MW (Advanced - HR 4900) & 5,610 & 1,642 & 4,900 & 799 & 2,441 \\
\hline $\begin{array}{l}\text { 5+ MW (Traditional - reciprocating } \\
\text { turbine) }\end{array}$ & 5,500 & 13 & 6,040 & 1 & 14 \\
\hline $\begin{array}{l}1-5 \mathrm{MW} \text { (Traditional - reciprocating } \\
\text { turbine) }\end{array}$ & 5,150 & 1,787 & 6,080 & 179 & 1,966 \\
\hline $\begin{array}{l}\text { Under } 1 \mathrm{MW} \text { (Traditional - } \\
\text { reciprocating turbine) }\end{array}$ & 5,400 & 209 & 6,815 & 21 & 230 \\
\hline 0-2 MW (Traditional - microturbine) & 6,940 & 72 & $\mathrm{n} / \mathrm{a}$ & 0 & 72 \\
\hline Reference & & 1,855 & & 1,530 & 3,385 \\
\hline
\end{tabular}


Table A.2. Sources for CHP technology price and performance parameters.

\begin{tabular}{|c|c|}
\hline Price and operating parameter & Source/rationale \\
\hline \multicolumn{2}{|l|}{ Baseload CHP operation } \\
\hline Net heat rate (BTU/kWh HHV) & DOE CHP Technology Fact Sheet Series 2017 \\
\hline Nominal electric power $(\mathrm{kW})$ & DOE CHP Technology Fact Sheet Series 2017 \\
\hline Installed cost $(\$ / \mathrm{kW})$ & $\begin{array}{l}\text { DOE CHP Technology Fact Sheet Series 2017, escalated by } 10 \% \text { to get } \\
2024 \text { costs. } \\
\text { (Escalation based on producer price increases in the turbine and engine } \\
\text { market over the past } 5 \text { years [BLS data]) }\end{array}$ \\
\hline Variable O\&M (cents/kWh) & $\begin{array}{l}\text { DOE CHP Technology Fact Sheet Series } 2017 \text { escalated by } 1 \% \text { annually to } \\
\text { get } 2024 \text { costs. (Escalation based on the following: EIA report used } 1.6 \% \text {, } \\
\text { WECC report used } 0 \%, 1 \% \text { chosen as a conservative estimate) }\end{array}$ \\
\hline \multicolumn{2}{|l|}{ Operation at surplus } \\
\hline Heat rate (BTU/kWh HHV) & DOE CHP Technology Fact Sheet Series 2017 \\
\hline Total capacity $(\mathrm{kW})$ & DOE CHP Technology Fact Sheet Series 2017 \\
\hline Surplus capacity $(\mathrm{kW})$ & DOE CHP Technology Fact Sheet Series 2017 \\
\hline Incremental installed cost $(\$ / \mathrm{kW})$ & Calculated based on the baseload installed cost and \% of surplus capacity \\
\hline Variable O\&M (cents/kWh) & $\begin{array}{l}\text { DOE CHP Technology Fact Sheet Series 2017, escalated by } 1 \% \text { annually to } \\
\text { get } 2024 \text { costs. } \\
\text { (Escalation based on the following: EIA report used } 1.6 \% \text {, WECC report } \\
\text { used } 0 \%, 1 \% \text { chosen as a conservative estimate) }\end{array}$ \\
\hline Thermal credit given & $\begin{array}{l}\text { Yes, for all but combustion turbines with steam injection (combustion } \\
\text { turbine with steam-injected gas turbine) } \\
\text { (CARB } 2007 \text { emissions regulations allow CHP systems to include both } \\
\text { the electric and thermal output in the calculation of output-based } \\
\text { emissions.) }\end{array}$ \\
\hline Operating limitation (hours/year) & DOE CHP Technology Fact Sheet Series 2017 \\
\hline
\end{tabular}

DOE CHP Technology Fact Sheet Series 2017. Accessed at: https://www.energy.gov/eere/amo/combined-heat-and-powerbasics; data obtained from Fact Sheets on Reciprocating Engines and Gas Turbines.

Energy Information Administration. Distributed Generation and Combined Heat and Power System Characteristics and Costs in the Buildings Sector, US EIA, April 2017, accessed at eia.gov/analysis/studies/buildings/distrigen/pdf/dg_chp.pdf.

Western Electric Coordinating Council. "Capital Cost Review of Power Generation Technologies," Western Electric Coordinating Council, March 2015, accessed at wecc.biz/Reliability/2014_TEPPC_Generation_CapCost_Report_E3.pdf.

Table A.3. Financial parameter universal assumptions.

\begin{tabular}{|l|l|}
\hline \multicolumn{1}{|c|}{ Assumption } & \multicolumn{1}{c|}{ Notes/Method } \\
\hline Project life & 10 years, starting in 2024 \\
\hline $\begin{array}{l}\text { Simple } \\
\text { payback } \\
\text { period }\end{array}$ & $\begin{array}{l}\text { Sites with <6 year simple payback are deemed to have economic potential } \\
\text { Payback calculations do not include capital cost reductions from the Federal Business Energy } \\
\text { Investment Tax Credit or incentive payments from California's Self Generation Incentive } \\
\text { Program }\end{array}$ \\
\hline $\begin{array}{l}\text { Tax rate and } \\
\text { depreciation }\end{array}$ & $\begin{array}{l}35 \%, \text { property taxes and insurance } \\
2 \% \text { of depreciated value (10 year straight-line schedule) }\end{array}$ \\
\hline
\end{tabular}

\section{Summary of equations used to calculate energy revenues in Table 6 of report:}

$\mathrm{n}=$ different types of generators

$\mathrm{i}=8760$ hours $\mathrm{i}=8760$ hours 
Energy Revenue $(\$)=\sum\left(\int_{\mathrm{i}=1}(\text { Generation }) * \int_{\mathrm{i}=1}(\text { Price Received })\right)_{\mathrm{n}}$ $\mathrm{i}=8760$ hours $\mathrm{i}=8760$ hours Ancillary Revenue $(\$)=\sum\left(\int_{\mathrm{i}=1}(\text { Provision }) * \int_{\mathrm{i}=1}(\text { Ancillary Price })\right)_{\mathrm{n}}$

Total Revenue $(\$)=$ Energy Revenue + Ancillary Revenue

$\mathrm{i}=8760$ hours $\mathrm{i}=8760$ hours $\mathrm{i}=8760$ hours

If $\left(\int_{i=1}(\text { Generation })_{n}-\int_{i=1}(\text { Baseload Capacity })\right)_{n}>\int_{i=1}(\text { Baseload Capacity })_{n}$ $\mathrm{i}=8760$ hours $\mathrm{i}=8760$ hours

Surplus Capacity $(M W)=\sum\left(\int_{\mathrm{i}=1}(\text { Generation })-\int_{\mathrm{i}=1}(\text { Baseload Capacity })\right)_{\mathrm{n}}$

Hours Operating at Surplus (hours) $=$

$\mathrm{i}=8760$ hours $\mathrm{i}=8760$ hours $\mathrm{i}=8760$ hours

$\sum\left(\left(\int_{i=1}(\text { Generation })-\int_{i=1}(\text { Baseload Capacity })\right)_{n}>\int_{i=1}(\text { Baseload Capacity })_{n}\right.$

Revenue ( $\$$ thousands per MW surplus $)=$

Total Revenue / (Surplus Capacity*1000)

*Generation: Energy provided by the generators to the grid (MW)

***Provision: It is the total reserve provided by the generator to meet the risk (risk is the megawatt requirement for reserves).

***Baseload Capacity: It is the minimum generation level of each generating unit. 



\section{APPENDIX B. CHP TECHNOLOGY OVERVIEW}

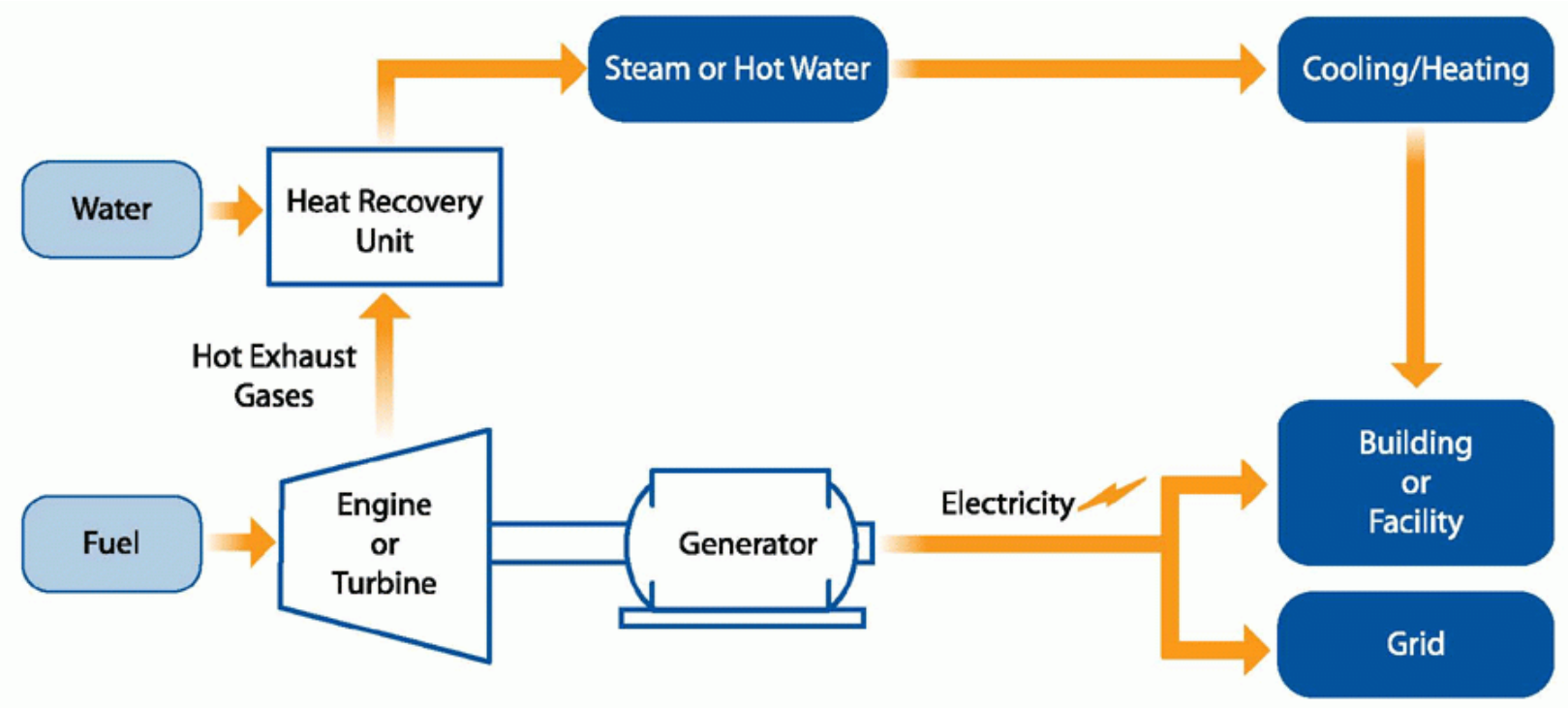

Figure 3. Organization of Combined Heat and Power Systems

Combined Heat and Power is a technology used to generate electricity while capturing the heat created through the power generation process. The heat is used to meet heating and/or cooling needs in the same facility. Key facts about CHP (also known as "cogeneration"):

- CHP is a highly efficient way to produce electricity-about $15-25 \%$ more efficient than traditional power generation.

- The efficiency of CHP results in lower GHG and criteria pollutant emissions.

- CHP is deployed at many industrial, commercial and institutional facilities throughout the United States, but it is still underutilized.

\section{Types of CHP Technology}

In developing the concepts of advanced CHP, both gas turbine and reciprocating engine concepts were characterized. Concepts deploying steam injection with gas turbines, which had been pioneered in the late 1970s and early 1980s, were evaluated because of their attractive generating efficiencies. The technology eventually was displaced by combined-cycle turbines, which are still the most prevalent form of natural gas-fired generation but are not typically employed at the scale for which CHP units are sized. CHP units employing steam injection remain a practical option to temporarily increase generation efficiency. However, the impact of supplying thermal energy to replace the thermal energy used for steam injection resulted in a lower efficiency when both thermal and electric outputs were considered, as is critical for $\mathrm{CHP}$ concepts. Ultimately in the analysis, the reciprocating engine options were found to be economically preferable and thus are the only options included in the final results. 


\section{Reciprocating-Inverter}

Reciprocating engine CHP units coupled with inverter technology offer limited operation at higher output, which creates a surplus capacity that can be used to support the grid. Many smaller CHP units currently include this technology, as some states have more streamlined interconnection for inverter units. It allows units to operate more efficiently at part loads while also providing peak power beyond continuous ratings for limited periods of time. Larger CHP units without inverters tend to have stricter limits on the time and capacity increase for peak power.

Advanced technology: The analysis assumes that reciprocating engine units of up to $5 \mathrm{MW}$ capacity have inverter technology and can peak up to $25 \%$ of full load-rated power for up to 500 hours per year. Units of up to $2 \mathrm{MW}$ capacity have been produced, with demand currently limited for larger units. For these units to be economical for the CHP owner, the additional revenues from grid support must allow the owner to recover the additional investment in inverter technology; the added investment may increase the cost of the unit, particularly for larger units.

\section{Partly Loaded Reciprocating Engines}

Reciprocating engine CHP tends to be very efficient at part loads, down to $50 \%$ of full load or less. CHP units can be sized for greater than the site baseload to include surplus capacity which can be used to support the grid. Although these units are still very efficient at lower loads, their efficiency improves as they generate more power; as a result, their efficiency for grid support is even higher.

Advanced technology: In the analysis, part-loaded reciprocating engines with inverters reserve 60 or $75 \%$ of full capacity for site use and the balance for grid support, using technology currently available. To be economical for the CHP owner, the added investment required to install a larger unit must be recovered through grid support revenues or potentially through other benefits; these include site resiliency resulting from the capability to keep the entire facility operating during grid outages. This option has the highest cost of surplus capacity, but it is not constrained in terms of hours of operation and may be used more extensively to recover the added investment.

Table B.1 considers the breadth of advanced options considered in the analysis. Table B.2 portrays the traditional CHP options, and Table B.3 provides an example calculation for the derivation of advanced characteristics, based on traditional price and performance data. 
Table B.1. Aggressive flexible CHP options and value of simple dispatch grid support (year 2024).

\begin{tabular}{|c|c|c|c|c|c|c|c|c|c|c|c|c|c|c|c|c|c|}
\hline Size range & $\begin{array}{c}0.1-0.8 \\
\text { MW }\end{array}$ & $\begin{array}{c}0.8-2.0 \\
\text { MW }\end{array}$ & \multicolumn{3}{|c|}{ 2-5 MW } & \multicolumn{4}{|c|}{ 5-10 MW } & \multicolumn{4}{|c|}{ 10-20 MW } & \multicolumn{4}{|c|}{$20+M W$} \\
\hline Technology & $\begin{array}{l}\text { Recip + } \\
\text { Inverter }\end{array}$ & $\begin{array}{l}\text { Recip + } \\
\text { Inverter }\end{array}$ & $\begin{array}{l}\text { Recip + } \\
\text { Inverter }\end{array}$ & $\begin{array}{l}\text { Recip } \\
@ 60 \%\end{array}$ & $\begin{array}{c}\text { CT } \\
\text { with } \\
\text { STIG }\end{array}$ & $\begin{array}{l}\text { Recip } \\
\text { @ 60\% }\end{array}$ & Recip & $\begin{array}{c}\text { CT } \\
\text { with } \\
\text { STIG }\end{array}$ & \begin{tabular}{|c} 
CT with \\
STIGCH \\
P
\end{tabular} & $\begin{array}{l}\text { Recip } \\
\text { @ 75\% }\end{array}$ & Recip & \begin{tabular}{|} 
CT with \\
STIGCH \\
P
\end{tabular} & $\begin{array}{c}\text { CT } \\
\text { with } \\
\text { STIG }\end{array}$ & $\begin{array}{l}\text { Recip } \\
\text { @ 75\% }\end{array}$ & Recip & $\begin{array}{c}\text { CT with } \\
\text { STIGCH } \\
\text { P }\end{array}$ & \begin{tabular}{|c|} 
CT \\
with \\
STIG
\end{tabular} \\
\hline Operation of CHP unit & & & & & & & & & & & & & & & & & \\
\hline $\begin{array}{r}\text { Installed cost }(\$ / \mathrm{kW}) \text { without } \\
\text { surplus capability }\end{array}$ & $\$ 3,075$ & $\$ 2,566$ & $\$ 1,949$ & $\$ 2,566$ & $\begin{array}{r}\$ 3,05 \\
1 \\
\end{array}$ & $\$ 1,548$ & $\begin{array}{r}\$ 1,54 \\
8 \\
\end{array}$ & $\$ 2,184$ & $\$ 2,229$ & $\$ 1,436$ & $\begin{array}{r}\$ 1,54 \\
8\end{array}$ & $\$ 1,642$ & $\begin{array}{r}\$ 1,59 \\
7 \\
\end{array}$ & $\$ 1,324$ & $\begin{array}{r}\$ 1,54 \\
8 \\
\end{array}$ & $\$ 1,427$ & $\begin{array}{r}\$ 1,38 \\
2 \\
\end{array}$ \\
\hline $\begin{array}{r}\text { Installed cost }(\$ / \mathrm{kW}) \text { of CHP } \\
\text { unit with surplus capability }\end{array}$ & $\$ 3,400$ & $\$ 2,891$ & $\$ 2,274$ & $\$ 3,304$ & $\begin{array}{r}\$ 3,28 \\
8 \\
\end{array}$ & $\$ 2,625$ & NA & $\$ 2,421$ & $\$ 2,466$ & $\$ 2,065$ & NA & $\$ 1,879$ & $\begin{array}{r}\$ 1,83 \\
4 \\
\end{array}$ & $\$ 1,766$ & NA & $\$ 1,663$ & $\begin{array}{r}\$ 1,61 \\
8 \\
\end{array}$ \\
\hline $\begin{array}{r}\text { Nominal electric power } \\
(\mathrm{kW})\end{array}$ & 633 & 1,141 & 3,325 & 1,611 & 4,600 & 5,511 & 9,341 & 7,965 & 7,965 & 14,012 & $\begin{array}{r}18,68 \\
2 \\
\end{array}$ & 21,745 & $\begin{array}{r}21,74 \\
5 \\
\end{array}$ & 21,017 & $\begin{array}{r}28,02 \\
3 \\
\end{array}$ & 43,069 & $\begin{array}{r}43,06 \\
9 \\
\end{array}$ \\
\hline $\begin{array}{r}\text { Net electric power } \\
(\mathrm{kW})\end{array}$ & 633 & 1,141 & 3,325 & 1,611 & 4,324 & 5,511 & 9,341 & 7,487 & 7,487 & 14,012 & $\begin{array}{r}18,68 \\
2 \\
\end{array}$ & 20,440 & $\begin{array}{r}20,44 \\
0 \\
\end{array}$ & 21,017 & $\begin{array}{r}28,02 \\
3 \\
\end{array}$ & 40,485 & $\begin{array}{r}40,48 \\
5 \\
\end{array}$ \\
\hline Thermal output (MBTU/kWh) & 4.5 & 3.9 & 3.2 & 3.9 & 5.5 & 3.2 & 2.8 & 4.6 & 4.6 & 3.0 & 2.8 & 3.6 & 3.6 & 3.0 & 2.8 & 3.1 & 3.1 \\
\hline $\begin{array}{r}\text { Heat rate } \\
(\mathrm{BTU} / \mathrm{kWh} \mathrm{HHV}) \\
\end{array}$ & 9,890 & 9,074 & 8,342 & 9,712 & $\begin{array}{r}13,64 \\
8 \\
\end{array}$ & 8,904 & 8,143 & 11,685 & 11,685 & 8,904 & 8,143 & 10,308 & $\begin{array}{r}10,30 \\
8 \\
\end{array}$ & 8,904 & 8,143 & 9,611 & 9,611 \\
\hline $\begin{array}{r}\text { Net heat rate } \\
\text { (BTU/kWh HHV) }\end{array}$ & 5,403 & 5,166 & 5,127 & 5,778 & 8,170 & 5,737 & 5,296 & 7,127 & 7,127 & 5,905 & 5,296 & 6,749 & 6,749 & 5,905 & 5,296 & 6,505 & 6,505 \\
\hline $\begin{array}{r}\text { Variable O\&M } \\
\text { (cents } / \mathrm{kWh}) \\
\end{array}$ & 2.5 & 2.3 & 1.9 & 1.7 & 1.4 & 1.0 & 1.0 & 1.3 & 1.3 & 1.0 & 1.0 & 1.0 & 1.0 & 1.0 & 1.0 & 1.0 & 1.0 \\
\hline Operation at surplus capacity & & & & & & & & & & & & & & & & & \\
\hline $\begin{array}{l}\text { Incremental installed cost } \\
(\$ / \mathrm{kW}) \text { for surplus capacity }\end{array}$ & $\$ 1,200$ & $\$ 1,200$ & $\$ 1,200$ & $\$ 1,061$ & $\$ 390$ & $\$ 1,453$ & NA & $\$ 390$ & $\$ 435$ & $\$ 1,096$ & NA & $\$ 618$ & $\$ 573$ & $\$ 985$ & NA & $\$ 618$ & $\$ 573$ \\
\hline $\begin{array}{r}\text { Total capacity } \\
(\mathrm{kW}) \\
\end{array}$ & 791 & 1,426 & 4,156 & 2,731 & 7,117 & 9,341 & NA & 12,323 & 12,323 & 18,682 & NA & 29,429 & $\begin{array}{r}29,42 \\
9 \\
\end{array}$ & 28,023 & NA & 58,290 & $\begin{array}{r}58,29 \\
0 \\
\end{array}$ \\
\hline $\begin{array}{r}\text { Surplus capacity } \\
(\mathrm{kW}) \\
\end{array}$ & 158 & 285 & 831 & 1,120 & 2,793 & 3,830 & NA & 4,358 & 4,836 & 4,689 & NA & 8,989 & 7,684 & 7,006 & NA & 15,221 & $\begin{array}{r}15,22 \\
1 \\
\end{array}$ \\
\hline Net heat rate (BTU/kWh HHV) & 6,661 & 6,897 & 6,540 & 4,986 & 4,045 & 4,892 & NA & 3,463 & 7,383 & 4,925 & NA & 7,921 & 3,138 & 4,925 & NA & 7,874 & 3,699 \\
\hline $\begin{array}{r}\text { Operating limitation } \\
\text { (Hours/year) }\end{array}$ & 500 & 500 & 500 & 6,000 & 500 & 6,000 & NA & 500 & 500 & 6,000 & NA & 500 & 500 & 6,000 & NA & 500 & 500 \\
\hline
\end{tabular}

Notes: Based on DOE Tech Characterizations, costs escalated to 2024. Some improvements to part-load efficiency of advanced recip units assumed.

Variable cost based on \$8.1/MMBTU forecasted natural gas price to industrial users.

Steam generation for STIG CHP at $\$ 45 / \mathrm{kW}$ per Jacobs Engineering.

$\mathrm{HHV}=$ higher heating value; STIG = steam injection gas turbine. 
Table B.2. Traditional CHP Options (year 2024) (continued).

\begin{tabular}{|c|c|c|c|c|c|c|c|c|c|c|c|}
\hline Size range & $\begin{array}{c}0.1-0.8 \\
\text { MW }\end{array}$ & $\begin{array}{c}0.8-2.0 \\
\text { MW }\end{array}$ & \multicolumn{3}{|c|}{ 2-5 MW } & \multicolumn{2}{|c|}{ 5-10 MW } & \multicolumn{2}{|c|}{ 10-20 MW } & \multicolumn{2}{|c|}{$20+\mathrm{MW}$} \\
\hline Technology & $\begin{array}{l}\text { Recip + } \\
\text { Inverter }\end{array}$ & $\begin{array}{l}\text { Recip + } \\
\text { Inverter }\end{array}$ & $\begin{array}{l}\text { Recip + } \\
\text { Inverter }\end{array}$ & Recip & $\mathrm{CT}$ & Recip & $\mathrm{CT}$ & Recip & $\mathrm{CT}$ & Recip & $\mathrm{CT}$ \\
\hline Operation of CHP unit & & & & & & & & & & & \\
\hline $\begin{array}{r}\text { Installed cost }(\$ / \mathrm{kW}) \text { of } \mathrm{CHP} \\
\text { unit }\end{array}$ & $\$ 3,075$ & $\$ 2,566$ & $\$ 2,274$ & $\$ 1,949$ & $\$ 3,051$ & $\$ 1,548$ & $\$ 2,184$ & $\$ 1,436$ & $\$ 1,597$ & $\$ 1,324$ & $\$ 1,382$ \\
\hline $\begin{array}{r}\text { Net electric power } \\
(\mathrm{kW})\end{array}$ & 633 & 1,141 & 3,325 & 3,325 & 4,324 & 9,341 & 7,487 & 18,682 & 20,440 & 28,023 & 40,485 \\
\hline $\begin{array}{l}\text { Thermal output } \\
\text { (MBTU/kWh) }\end{array}$ & 4.5 & 3.9 & 3.2 & 3.2 & 5.5 & 2.8 & 4.6 & 2.8 & 3.6 & 2.8 & 3.1 \\
\hline $\begin{array}{r}\text { Heat rate } \\
(\mathrm{BTU} / \mathrm{kWh} \mathrm{HHV})\end{array}$ & 9,890 & 9,074 & 8,342 & 8,342 & 13,648 & 8,342 & 11,685 & 8,207 & 10,308 & 8,207 & 9,611 \\
\hline $\begin{array}{r}\text { Variable O\&M } \\
(\$ / \mathrm{MWh})\end{array}$ & 25.0 & 22.6 & 19.1 & 19.1 & 14.1 & 16.0 & 13.0 & 9.7 & 9.7 & 9.7 & 9.7 \\
\hline $\begin{array}{r}\text { Incremental installed cost } \\
(\$ / \mathrm{kW}) \text { for overload capacity }\end{array}$ & $\$ 0$ & $\$ 0$ & $\mathrm{NA}$ & $\$ 0$ & NA & $\$ 0$ & NA & $\$ 0$ & NA & $\$ 0$ & NA \\
\hline $\begin{array}{r}\text { Total capacity } \\
(\mathrm{kW})\end{array}$ & 696 & 1,255 & NA & 3,658 & NA & 10,275 & NA & 20,550 & NA & 30,825 & NA \\
\hline $\begin{array}{r}\text { Overload capacity } \\
(\mathrm{kW})\end{array}$ & 63 & 114 & NA & 333 & NA & 934 & NA & 1,868 & NA & 2,802 & NA \\
\hline $\begin{array}{r}\text { Net heat rate (BTU/kWh } \\
\text { HHV) of overload capacity }\end{array}$ & 6,815 & 6,087 & NA & 6,072 & NA & 6,039 & NA & 6,039 & NA & 6,039 & NA \\
\hline
\end{tabular}

Notes: Based on DOE Tech Characterizations, costs escalated to 2024. Some improvements to part load efficiency of advanced recip units assumed.

Variable cost based on $\$ 8.1 /$ MMBTU forecasted natural gas price to industrial users.

Steam generation for STIGCHP at $\$ 45 / \mathrm{kW}$ per Jacobs Engineering. 
Table B.3. Example calculations for advanced CHP units.

$\begin{array}{lc}\text { Size range } & \text { 20+ MW } \\ \text { Technology } & \text { Recip } \\ \text { Advanced technology } & \text { Recip @ 75\% }\end{array}$

Technology

Recip

Advanced technology

Notes: This process was employed for each of the advanced CHP unit size ranges. The 20+ MW was chosen for the

example, as it has the most steps. Line 2 is not employed with the other size ranges; it is also employed with the 10-20

MW size range. These two are the only size ranges for which multiple CHP units are required.

DOE Fact Sheet for Reciprocating Engines can be found at https://www.energy.gov/eere/amo/downloads/reciprocating engines-doe-chp-technology-fact-sheet-series-fact-sheet-2016

\begin{tabular}{l|l|l|l|l|l}
\hline Line & Characteristic & Calculation & Result & Units
\end{tabular}
Capability, Single Unit, Year 2024

2 Installed Cost of CHP With Surplus

Capability, Multiple Units

$1548 \quad \$ / \mathrm{kW}$

Capacity of $9341 \mathrm{~kW}$ unit from DOE CHP Fact Sheet for Reciprocating Engines (2016), Table 2-2

Escalation from 2016 to 2024 at $1 \%$ annual, based on BLS data on engines and turbine cost escalations previous 5 years (Source: Bureau of Labor Statistics, Engines and Turbine Machinery segment)

\begin{tabular}{|l|c|c|c|c|}
\hline Capability, Multiple Units & 1,358 & $\$ / k W$ & $\begin{array}{l}\text { Multi- } \\
(2015 \$\end{array}$ \\
\hline
\end{tabular}

Escalated to 2024 using $1 \%$ over 9 years $(1.093 \times 980=\$ 1072 / \mathrm{kW})$. Based on this data, estimate $\$ 95 / \mathrm{kW}$ reduction per additional unit

\begin{tabular}{|l|l|l|l|l|}
\hline & & & & \\
\hline
\end{tabular}

3 Nominal Electric Power, Full Capacity

4 Net Electric Power, Ful

Capacity

5 Total Installed Cost

6 Capacity Reserved for Site $(75 \%)$

7 Surplus Capacity

8 Installed Cost of CHP

With Surplus Capability

9 Thermal Output at Full Capacity

10 Heat Rate at Full Capacity

11 Electrical Efficiency at Full Capacity

12 Electrical Efficiency at $75 \%$ Capacity

13 Heat Rate at 75\% Capacity

14 Thermal Output at 75\% Capacity

15 Net Heat Rate

\begin{tabular}{l|l|l}
\hline & $8616 \mathrm{BTU} / \mathrm{kWh} \cdot 2.8$ \\
\hline
\end{tabular} MBTU/kWh*1000

BTU/MBTU

16 Variable O\&M directly from source

Units in estimate were not using heat recovery but included radiator for heat rejection to air, which can be more costly that heat recovery to water

Source: Rochester Public Utilities 2015 Update of the RPU Infrastructure Plan Generation Technology Assessment, Burns and McDonnell, June 2015

\begin{tabular}{|l|l|l|l}
$9341 \mathrm{~kW} /$ unit $\times 3$ units & 28,023 & $\mathrm{~kW}$ & Capacity of DOE CHP Fact Sheet for Reciprocating Engines (2016), Table 2-2
\end{tabular}

\begin{tabular}{|c|c|l|l|l|l}
$\$ 1,324 / \mathrm{kW} \times 28,023 \mathrm{~kW}$ & $\$ 38.1$ & & Capacity of $9341 \mathrm{~kW}$ unit from DOE CHP Fact Sheet for Reciprocating Engines (2016), Table 2-2
\end{tabular}

$28,023 \mathrm{~kW} \times .075$

\begin{tabular}{l|l|l|l}
$28,023 \mathrm{~kW}-21,017 \mathrm{~kW}$ & 7,006 & $\mathrm{~kW}$ & $($ Line $3 \times 75 \%)$ \\
\hline
\end{tabular}

\begin{tabular}{|l|l|l|l}
$\$ 38,068,828 / 21,017 \mathrm{~kW}$ & 1,811 & $\$ / \mathrm{kW}$ & (Line 3-Line 5)
\end{tabular}

\begin{tabular}{c|c|l|l}
$(26,600 \mathrm{MBTU} / \mathrm{h} \times 3$ units $)$ & 2.85 & MBTU/kWh & $($ Line 4/Line 6)
\end{tabular}

directly from source

directly from source

$0.945 \times 41.6 \%$

$3412 / 0.396$

\begin{tabular}{|c|l|l|}
\hline 6,616 & BTU/kWh \\
\hline
\end{tabular}

HHV

\begin{tabular}{l|l} 
BTU/kWh & DOE CHP Fact Sheet for Reciprocating Engines (2016), Table 2-2. \\
HHV &
\end{tabular}

(3412/Line 9)

(3412/Line 9)

CHP Catalog of Technologies, EPA 2015, Figure 2-3. Wartsilla Part Load Curve, unit is $94.5 \%$ of full load efficiency

MBTU/kWh $(3412 /$ Line 11$)$

BTU/kWh

Estimated heat recovery of $60 \%$ of heat input less energy value of electricity, consistent with heat recovery share of full load output $(76.06 \mathrm{MMBTU} / \mathrm{h} \cdot 31.87 \mathrm{MMBTU} / \mathrm{h}) \times 0.6=26.6 \mathrm{MMBTU} / \mathrm{h}$ heat recovered at full capacity

cents/kWh

Line $13-($ Line $14 \times 1000$ BTU/MBTU) 
Table B.3. Example calculations for advanced CHP units (continued).

\begin{tabular}{|c|c|c|c|c|c|}
\hline & $\begin{array}{l}\text { Size range } \\
\text { Technology } \\
\text { Advanced technology }\end{array}$ & $\begin{array}{l}\text { 20+ MW } \\
\text { Recip } \\
\text { Recip@ } 95 \%\end{array}$ & & \multicolumn{2}{|c|}{$\begin{array}{l}\text { Notes: This process was employed for each of the advanced CHP unit size ranges. The } 20+\mathrm{MW} \text { was chosen for the } \\
\text { example, as it has the most steps. Line } 2 \text { is not employed with the other size ranges; it is also employed with the } 10-20 \\
\text { MW size range. These two are the only size ranges for which multiple CHP units are required. } \\
\text { DOE Fact Sheet for Reciprocating Engines can be found at https://www.energy.gov/eere/amo/downloads/reciprocating- } \\
\text { engines-doe-chp-technology-fact-sheet-series-fact-sheet-2016 }\end{array}$} \\
\hline$\frac{\text { Line }}{\#}$ & $\underline{\text { Characteristic }}$ & Calculation & Result & Units & Source \\
\hline 17 & $\begin{array}{l}\text { Incremental Installed Cost for } \\
\text { Surplus Capacity }\end{array}$ & & & & CHP Fact Sheet for Reciprocating Engines (2016), Table 2-2. \\
\hline $17 \mathbf{a}$ & $\begin{array}{l}\text { Installed Cost/kW with Surplus } \\
\text { Capability }\end{array}$ & Line 2 & 1,358 & $\$ / \mathrm{kW}$ & $\begin{array}{l}\text { First, cost of CHP unit with surplus capacity is taken from Line } 8 \text { (above), and cost of unit without } \\
\text { surplus is subtracted. Cost of unit without surplus is determined by } \$ / \mathrm{kW} \text { installed for unit sized at } \\
\text { capacity reserved for site use }\end{array}$ \\
\hline $17 \mathrm{~b}$ & $\begin{array}{l}\text { Installed Cost with Surplus } \\
\text { Capability }\end{array}$ & Line 5 & $\begin{array}{l}\$ 38.1 \\
\text { million }\end{array}$ & & $\begin{array}{l}\text { In this case, } 21,017 \mathrm{~kW} \text { is estimated at } \$ 1,548 / \mathrm{kW} \text { less } \$ 95 / \mathrm{kW} \text { for a second unit, as approximately } 2 \\
\text { units of } 9341 \mathrm{~kW} \text { is closest to } 21017 \mathrm{~kW}\end{array}$ \\
\hline $17 \mathrm{c}$ & $\begin{array}{l}\text { Installed Cost/kW of CHP without } \\
\text { Surplus Capability }\end{array}$ & $1548-1 \times 95$ & 1,453 & $\$ / \mathrm{kW}$ & CHP Fact Sheet for Reciprocating Engines (2016), Table 2-2. \\
\hline 17d & \begin{tabular}{|l|} 
Installed Cost of CHP without \\
Surplus Capability \\
\end{tabular} & $\$ 1,453 / \mathrm{kW} \times 21,017 \mathrm{~kW}$ & $\begin{array}{l}\$ 30.5 \\
\text { million }\end{array}$ & & Line 1 above less $\$ 95 / \mathrm{kW}$ as described in Line 2 above \\
\hline $17 \mathrm{e}$ & \begin{tabular}{l|l} 
Incremental Cost of \\
Surplus Capacity
\end{tabular} & $38,068,828-30,537,701$ & $\begin{array}{c}\$ 7.53 \\
\text { million }\end{array}$ & & $($ Line $17 \mathrm{c} \times$ Line 6$)$ \\
\hline 20 & \multicolumn{5}{|l|}{ Incremental Heat Rate } \\
\hline 20a & $\begin{array}{l}\text { Fuel Used at Full } \\
\text { Capacity }\end{array}$ & $\begin{array}{l}8143 \mathrm{BTU} / \mathrm{kWh} \times 28,023 \\
\mathrm{~kW}\end{array}$ & $\begin{array}{c}228 \\
\text { million }\end{array}$ & BTU/h & (Line $10 \times$ Line 4$)$ \\
\hline $20 \mathrm{~b}$ & $\begin{array}{l}\text { Fuel Used at } 75 \% \\
\text { Capacity }\end{array}$ & $\begin{array}{c}8617 \mathrm{BTU} / \mathrm{kWh} \times 21,017 \\
\mathrm{~kW}\end{array}$ & $\begin{array}{c}181 \\
\text { million }\end{array}$ & $\mathrm{BTU} / \mathrm{h}$ & (Line $13 \times$ Line 6$)$ \\
\hline $20 \mathrm{c}$ & Net Fuel Used by Surplus & $\begin{array}{c}228 \mathrm{MMBTU} / \mathrm{h}- \\
181 \mathrm{MMBTU} / \mathrm{h}\end{array}$ & 47 & MMBTU/h & $($ Line13 $\times$ Line 17) \\
\hline 20d & $\begin{array}{l}\text { Incremental Heat Rate of } \\
\text { Surplus Capacity }\end{array}$ & $47 \mathrm{MMBTU} / \mathrm{h} / 7,006 \mathrm{~kW}$ & 6,721 & $\begin{array}{l}\text { BTU/kWh } \\
\text { HHV }\end{array}$ & (Line 20c / Line 7) \\
\hline 21 & $\begin{array}{l}\text { Thermal Output of } \\
\text { Surplus Capacity }\end{array}$ & $0.60 \times(6721-3412) / 1000$ & 1.99 & MBTU/kWh & $\begin{array}{l}\text { Estimated heat recovery of } 60 \% \text { of heat input less energy value of electricity, consistent with heat } \\
\text { recovery share of full load output. This is viewed as conservative since there will likely be higher } \\
\text { temperature due to the lower efficiency. }\end{array}$ \\
\hline 22 & Net Heat Rate & $\begin{array}{l}6724 \mathrm{BTU} / \mathrm{kWh}-1.99 \\
\mathrm{MBTU} / \mathrm{kWh} \cdot 1000 \\
\mathrm{BTU} / \mathrm{MBTU} \times 0.90\end{array}$ & 4,934 & $\begin{array}{l}\text { BTU/kWh } \\
\text { HHV }\end{array}$ & $\begin{array}{l}\text { Line } 20 \mathrm{~d} \times \text { Line } 21 \times 1000 \times 0.90 \text { ) It is assumed that } 90 \% \text { of the heat from surplus capacity use can be } \\
\text { recovered. } \\
\text { The majority of the segments with CHP potential had sufficient thermal demands to use all the surplus } \\
\text { heat, but it was assumed that all could use } 90 \% \text { of the heat. } \\
\text { The two segments that lacked sufficient heat load for } 100 \% \text { were industrial gases and correctional } \\
\text { institutions. Assumptions to facility changes were made to allow for more heat use, favoring the lower } \\
\text { cost of thermal vs. electricity in California. } \\
\text { Industrial gases were identified as candidates for a new thermally based process that has been developed, } \\
\text { and correctional facilities were assumed to have adopted absorption cooling to increase heat load. }\end{array}$ \\
\hline 23 & $\begin{array}{l}\text { Operating Limitation } \\
\text { (Hours/year) }\end{array}$ & $\begin{array}{l}5 \text { days/week } \times 24 \text { h/day } \times \\
50 \text { weeks }\end{array}$ & 6,000 & hours & Based on typical three shift, $24 \times 75$ day per week operation \\
\hline 24 & Variable O\&M & directly from source & 1.00 & Cents/kWh & CHP Fact Sheet for Reciprocating Engines (2016), Table 2-2. \\
\hline
\end{tabular}




\section{APPENDIX C. PAYBACK PERIOD DATA}

Table 10. Payback period data by scenario.

\begin{tabular}{|c|c|c|c|c|}
\hline $\begin{array}{c}\text { Payback periods by } \\
\text { scenario and CHP } \\
\text { unit size }\end{array}$ & $\begin{array}{l}\text { Without grid } \\
\text { revenues }\end{array}$ & With grid revenues & $\begin{array}{l}\text { With grid revenues } \\
\text { and } \$ 20 / \mathrm{MW} \\
\text { capacity payment }\end{array}$ & $\begin{array}{l}\text { With grid revenues } \\
\text { and } \$ 100 / \mathrm{MW} \\
\text { capacity payment }\end{array}$ \\
\hline \multicolumn{5}{|l|}{ Traditional } \\
\hline \multicolumn{5}{|l|}{ Number of sites } \\
\hline All CHP units & Avg: 4.6 years & Avg: 4.6 years & Avg: 4.4 years & Avg: 3.8 years \\
\hline$>6$ years & 199 & 213 & 163 & 1 \\
\hline 4-6 years & 811 & 720 & 701 & 622 \\
\hline$<4$ years & 399 & 476 & 545 & 786 \\
\hline $5+M W$ & Avg: 3.1 years & Avg: 2.7 years & Avg: 2.6 years & Avg: 2.3 years \\
\hline$>6$ years & 0 & 0 & 0 & 0 \\
\hline $4-6$ years & 23 & 1 & 1 & 0 \\
\hline$<4$ years & 143 & 165 & 165 & 166 \\
\hline Under 5 MW & Avg: 4.8 years & Avg: 4.8 years & Avg: 4.6 years & Avg: 4.1 years \\
\hline$>6$ years & 199 & 213 & 163 & 1 \\
\hline 4-6 years & 788 & 719 & 700 & 622 \\
\hline$<4$ years & 256 & 311 & 380 & 620 \\
\hline \multicolumn{5}{|c|}{ Baseload capacity (MW) } \\
\hline Total & 3,722 & 3,722 & 3,722 & 3,722 \\
\hline$>6$ years & 202 & 215 & 162 & 1 \\
\hline $4-6$ years & 1,442 & 1,234 & 1,133 & 739 \\
\hline$<4$ years & 2,078 & 2,273 & 2,428 & 2,983 \\
\hline 5+MW & 1,655 & 1,655 & 1,655 & 1,655 \\
\hline$>6$ years & 202 & 215 & 162 & 1 \\
\hline 4-6 years & 1,258 & 1,224 & 1,123 & 739 \\
\hline$<4$ years & 608 & 628 & 783 & 1,328 \\
\hline Under 5 MW & 2,068 & 2,068 & 2,068 & 2,068 \\
\hline$>6$ years & - & - & - & - \\
\hline 4-6 years & 184 & 10 & 10 & - \\
\hline$<4$ years & 1,471 & 1,645 & 1,645 & 1,655 \\
\hline \multicolumn{5}{|l|}{ Advanced } \\
\hline \multicolumn{5}{|l|}{ Number of sites } \\
\hline Total & Avg: 5.7 years & Avg: 5.2 years & Avg: 5.0 years & Avg: 4.4 years \\
\hline$>6$ years & 536 & 518 & 465 & 124 \\
\hline 4-6 years & 762 & 614 & 627 & 752 \\
\hline$<4$ years & 111 & 277 & 317 & 533 \\
\hline $5+M W$ & Avg: 4.7 years & Avg: 1.7 years & Avg: 1.6 years & Avg: 1.6 years \\
\hline$>6$ years & 16 & 0 & 0 & 0 \\
\hline 4-6 years & 122 & 0 & 0 & 0 \\
\hline$<4$ years & 28 & 166 & 166 & 166 \\
\hline Under 5 MW & Avg: 5.8 years & Avg: 5.7 years & Avg: 5.5 years & Avg: 4.8 years \\
\hline$>6$ years & 520 & 518 & 465 & 124 \\
\hline 4-6 years & 640 & 614 & 627 & 752 \\
\hline$<4$ years & 83 & 111 & 151 & 367 \\
\hline
\end{tabular}


Table 11. Payback period data by scenario (continued).

\begin{tabular}{|c|c|c|c|c|}
\hline $\begin{array}{c}\text { Payback periods by } \\
\text { scenario and CHP } \\
\text { unit size }\end{array}$ & $\begin{array}{l}\text { Without grid } \\
\text { revenues }\end{array}$ & With grid revenues & $\begin{array}{l}\text { With grid revenues } \\
\text { and } \$ 20 / \mathrm{MW} \\
\text { capacity payment }\end{array}$ & $\begin{array}{l}\text { With grid revenues } \\
\text { and } \$ 100 / \mathrm{MW} \\
\text { capacity payment }\end{array}$ \\
\hline \multicolumn{5}{|c|}{ Baseload capacity (MW) } \\
\hline Total & 3,722 & 3,722 & 3,722 & 3,722 \\
\hline$>6$ years & 757 & 628 & 538 & 156 \\
\hline 4-6 years & 2,274 & 1,121 & 1,113 & 992 \\
\hline$<4$ years & 691 & 1,974 & 2,072 & 2,575 \\
\hline $5+M W$ & 1,655 & 1,655 & 1,655 & 1,655 \\
\hline$>6$ years & 125 & - & - & - \\
\hline 4-6 years & 1,068 & - & - & - \\
\hline$<4$ years & 462 & 1,655 & 1,655 & 1,655 \\
\hline Under 5 MW & 2,068 & 2,068 & 2,068 & 2,068 \\
\hline$>6$ years & 632 & 628 & 538 & 156 \\
\hline 4-6 years & 1,206 & 1,121 & 1,113 & 992 \\
\hline$<4$ years & 230 & 319 & 417 & 920 \\
\hline \multicolumn{5}{|l|}{ Combined } \\
\hline \multicolumn{5}{|l|}{ Number of sites } \\
\hline Total & Avg: 4.8 years & Avg: 4.5 years & Avg: 4.3 years & Avg: 3.8 years \\
\hline$>6$ years & 215 & 194 & 129 & 1 \\
\hline 4-6 years & 907 & 715 & 746 & 648 \\
\hline$<4$ years & 287 & 500 & 534 & 760 \\
\hline $5+M W$ & Avg: 4.7 years & Avg: 1.6 years & Avg: 1.6 years & Avg: 1.5 years \\
\hline$>6$ years & 16 & 0 & 0 & 0 \\
\hline 4-6 years & 120 & 0 & 0 & 0 \\
\hline$<4$ years & 30 & 166 & 166 & 166 \\
\hline Under 5 MW & Avg: 4.8 years & Avg: 4.8 years & Avg: 4.7 years & Avg: 4.1 years \\
\hline$>6$ years & 199 & 194 & 129 & 1 \\
\hline $4-6$ years & 787 & 715 & 746 & 648 \\
\hline$<4$ years & 257 & 334 & 368 & 594 \\
\hline \multicolumn{5}{|c|}{ Baseload capacity (MW) } \\
\hline Total & 3,722 & 3,722 & 3,722 & 3,722 \\
\hline$>6$ years & 327 & 220 & 134 & 1 \\
\hline $4-6$ years & 2,312 & 1,209 & 1,200 & 831 \\
\hline$<4$ years & 1,083 & 2,294 & 2,389 & 2,891 \\
\hline $5+$ MW & 1,655 & 1,655 & 1,655 & 1,655 \\
\hline$>6$ years & 125 & - & - & - \\
\hline $4-6$ years & 1,055 & - & - & - \\
\hline$<4$ years & 474 & 1,655 & 1,655 & 1,655 \\
\hline Under 5 MW & 2,068 & 2,068 & 2,068 & 2,068 \\
\hline$>6$ years & 202 & 220 & 134 & 1 \\
\hline 4-6 years & 1,257 & 1,209 & 1,200 & 831 \\
\hline$<4$ years & 609 & 639 & 734 & 1,236 \\
\hline
\end{tabular}




\section{APPENDIX D. VARIABLE COST TO GENERATE AMONG TYPES OF GRID GENERATION}

Table D.1. Variable cost to generate among types of grid generation.

\begin{tabular}{|c|c|c|c|c|c|c|c|c|c|}
\hline \multirow{2}{*}{$\begin{array}{c}\text { Type of } \\
\text { generator/fuel }\end{array}$} & \multirow{2}{*}{$\begin{array}{l}\text { Average } \\
\text { variable } \\
\text { cost to } \\
\text { generate } \\
(\$ / M W h)\end{array}$} & \multirow{2}{*}{$\begin{array}{l}\text { Modeled } \\
\text { capacity in } \\
\text { California } \\
\text { (MW) }\end{array}$} & \multirow{2}{*}{$\begin{array}{l}\text { Cumulative } \\
\text { capacity } \\
\text { (MW) }\end{array}$} & \multirow{2}{*}{$\begin{array}{c}\text { Typical } \\
\text { duration of } \\
\text { cycle }\end{array}$} & \multirow{2}{*}{$\begin{array}{l}\text { Impact of } \\
\text { startup } \\
\text { cost }\end{array}$} & \multirow{2}{*}{$\begin{array}{l}\text { Startup } \\
\text { cost } \\
(\$ / \mathrm{MW})\end{array}$} & \multicolumn{3}{|c|}{$\begin{array}{l}\text { A verage variable cost } \\
\text { to generate }(\$ / M W h) \\
\text { with startup costs }\end{array}$} \\
\hline & & & & & & & $1 \mathrm{~h}$ & $3 \mathrm{~h}$ & $6 \mathrm{~h}$ \\
\hline $\begin{array}{l}\text { Central station } \\
\text { renewables }\end{array}$ & 7.5 & 22,959 & 22,959 & Baseload & Minimal & NA & 7.52 & 7.52 & 7.52 \\
\hline $\begin{array}{l}\text { Baseload steam- } \\
\text { coal/nuclear }\end{array}$ & 16.0 & 4,489 & 27,448 & Baseload & Minimal & NA & 15.98 & 15.98 & 15.98 \\
\hline $\begin{array}{l}\text { Baseload steam- } \\
\text { biomass }\end{array}$ & 27.9 & 1,916 & 29,364 & Baseload & Minimal & NA & 27.87 & 27.87 & 27.87 \\
\hline $\begin{array}{l}\text { Combined-cycle } \\
\text { gas-single shaft }\end{array}$ & 31.4 & 2,079 & 31,444 & Intermediate & Significant & 84 & 115.36 & 59.36 & 45.36 \\
\hline $\begin{array}{l}\text { Combined-cycle } \\
\text { gas-multi shaft }\end{array}$ & 35.6 & 70,160 & 101,604 & Intermediate & Significant & 84 & 119.61 & 63.61 & 49.61 \\
\hline $\begin{array}{l}\text { Combustion } \\
\text { turbine-natural } \\
\text { gas }\end{array}$ & 37.7 & 15,593 & 117,196 & $\begin{array}{l}\text { Intermediate } \\
\text { /peaking }\end{array}$ & Significant & 84 & 121.72 & 65.72 & 51.72 \\
\hline $\begin{array}{l}\text { Steam turbine- } \\
\text { natural gas }\end{array}$ & 49.3 & 14,273 & 131,469 & $\begin{array}{l}\text { Intermediate } \\
\text { /peaking }\end{array}$ & Significant & 84 & 133.30 & 77.30 & 63.30 \\
\hline $\begin{array}{l}\text { Advanced CHP- } \\
\text { natural gas }\end{array}$ & 49.8 & 1324 & 132,793 & $\begin{array}{l}\text { Intermediate } \\
\text { /peaking }\end{array}$ & None & 0 & 49.80 & 49.80 & 49.80 \\
\hline
\end{tabular}

Note: Omits technology with total capacity under $1200 \mathrm{MW}$. 



\section{APPENDIX E. APPROACH TO VALUING THERMAL LOAD}

During the Phase I analysis, the analysis approach adopted a simplifying assumption that predicated a potential CHP site would not value additional thermal output, as the modeling of this aspect would be more involved than the study scope permitted. However, it was recognized that this assumption limited the value of flexible CHP to the site. During the Phase II analysis, this assumption was removed, initially with the assumption that sites could use all thermal output. Analysis of a few key sectors (food, paper, and petroleum industries) confirmed this was valid.

Subsequently, more comprehensive analysis was conducted to validate the assumption. It was found that there were some market segments with reduced thermal needs that could constrain full use of the thermal output from flexible CHP. Table E.1 presents the impact that shifting the site use of the CHP unit to reserve capacity for the grid support has on the power-to-heat ratio of the CHP unit.

Table E.1. Impact of shifting CHP power on power-to-heat ratio.

\begin{tabular}{|l|c|}
\hline Output condition & P/H Ratio \\
\hline Recip at full output & 1.19 \\
\hline Recip at $75 \%$ output & 1.09 \\
\hline Recip at $75 \%$ with surplus heat & 0.90 \\
\hline Recip at $60 \%$ output & 0.96 \\
\hline Recip at $60 \%$ output with surplus heat & 0.71 \\
\hline
\end{tabular}

Note: Power-to-heat ratio is defined as the ratio of the power $(\mathrm{kW})$ produced, converted to BTU using a $3412 \mathrm{BTU} / \mathrm{kWh}$ conversion factor, divided by the thermal output of the CHP unit (in BTU/h). Values above are derived from Table B-1, 5-10 MW and 10-20MW units.

As the units are asked to reserve more capacity, they support site loads at lower electrical efficiencies; therefore, their thermal output increases and the power-to-heat ratio decreases. As surplus heat is introduced without increasing the power output, the ratio declines further. As the ratio declines, the CHP unit's ability to support a wide range of sites is increasingly challenged. As shown in Table E.2, among selected commercial segments, some have ample thermal needs to support the use of surplus heat (e.g., hospitals and colleges), whereas others such as prisons/correctional institutions have lower thermal needs and thus do not tend to have thermal loads that support lower power-to-heat ratios.

Table E.2. Power-to-heat ratios of various commercial sites.

\begin{tabular}{|l|c|}
\hline \multicolumn{1}{|c|}{ Sites } & Average $\mathbf{P} / \mathbf{H}$ ratio of site \\
\hline Hospitals & 0.723 \\
\hline Colleges & 0.773 \\
\hline Government buildings & 1.097 \\
\hline Prisons & 1.511 \\
\hline
\end{tabular}

Source: US Department of Energy. Combined Heat and Power (CHP) Technical Potential in the United States,_Appendix B, Power to Heat Ratios, Washington DC, 2016. 
Note that these are typical power-to heat-ratios, and that each site will have unique power and thermal needs. Thus there are some prisons in California for which CHP still provides a good fit, and these sites have already adopted CHP.

Table E. 3 shows results for the analysis of individual market segments in which the power-to-heat ratio was compared with flexible CHP attributes to determine whether the typical site profile can accommodate the added thermal load. Most segments were capable of supporting the added load, but some key segments were not. However, sites can change their thermal loads by shifting energy uses to thermally based equipment. For example, many sites also adopt absorption chillers when they install CHP, as it becomes cost-effective to provide cooling with the captured thermal output as opposed to using gridsupplied electricity. One other large segment, industrial gas producers, was targeted for absorption-based processes, using thermal loads, to modify their thermal needs. Others were not identified with immediate solutions, but this was a smaller set (17\% of total large sites).

Table E.3. Analysis of sites comparing power-to-heat ratio and flexible CHP attributes.

\begin{tabular}{|l|c|c|c|}
\hline Characterization of site thermal loads & No. sites & $\begin{array}{c}\text { Capacity } \\
\text { (MW) }\end{array}$ & Share \\
\hline Adequate thermal loads & 89 & 939 & $57 \%$ \\
\hline Adequate with enhanced thermal loads & 48 & 440 & $27 \%$ \\
\hline Others & 29 & 276 & $17 \%$ \\
\hline Subtotal & 166 & 1,655 & $100 \%$ \\
\hline
\end{tabular}

Industrial gas producers (15) use a thermally enhanced absorption process. Correctional institutions (29) and large government buildings (4) apply absorption cooling. Others are assumed to be capable of enhancing thermal load.

For sites under $5 \mathrm{MW}$, the average hours of grid support are under 40. It is assumed that for these limited hours, the site can productively absorb the surplus thermal energy by expanding the temperature range of the building/site controls.

Finally, for the smaller CHP sites, the surplus thermal output was seldomly available, only 20-50 hours per year. So it was assumed that these sites would broaden their controls to allow for more thermal output to be temporarily absorbed within the facility, most likely by changing temperature set points. 